Portland State University

PDXScholar

$10-2018$

\title{
Human Settlement and Mid-Late Holocene Coastal Environmental Change at Cape Krusenstern, Northwest Alaska
}

Shelby Anderson

Portland State University, ashelby@pdx.edu

James Jordon

Antioch University

Adam Freeburg

University of Washington

Follow this and additional works at: https://pdxscholar.library.pdx.edu/anth_fac

Part of the Archaeological Anthropology Commons, and the Social and Cultural Anthropology Commons

Let us know how access to this document benefits you.

\section{Citation Details}

Published as: Anderson, S., Jordan, J., \& Freeburg, A. (2018). Human settlement and Mid-Late Holocene coastal environmental change at Cape Krusenstern, Northwest Alaska. Quaternary International.

This Post-Print is brought to you for free and open access. It has been accepted for inclusion in Anthropology Faculty Publications and Presentations by an authorized administrator of PDXScholar. Please contact us if we can make this document more accessible: pdxscholar@pdx.edu. 


\section{Human Settlement and Mid-Late Holocene Coastal Environmental Change at Cape Krusenstern, Northwest Alaska}

Shelby Anderson ${ }^{a}$ (Portland State University), James Jordan ${ }^{b}$ (Antioch University New England), Adam Freeburg ${ }^{c}$ (National Park Service/University of Washington)

${ }^{a}$ Corresponding Author: Portland State University, Department of Anthropology, P.O. Box 751, Portland, OR 97207, USA, ashelby@pdx.edu

${ }^{\mathrm{b}}$ Antioch University New England, Department of Environmental Studies, 41 Avon St., Keene, NH 03431, USA

'National Park Service, 4175 Geist Rd, Fairbanks, AK 99709 


\begin{abstract}
Archaeologists hypothesize that mid-late Holocene environmental variability played a role in several significant western Arctic cultural developments including population fluctuations, the evolution of Arctic maritime adaptations, and Arctic-wide migrations. Further evaluation of these hypotheses requires higher resolution archaeological and paleoecological datasets than are currently available. In response, we undertook an interdisciplinary study at Cape Krusenstern, a large coastal site complex in northwest Alaska, which was occupied over the last ca. 5000-6000 years. Our goals were to refine local cultural and paleoenvironmental chronologies and to explore the question of how local environmental change may have influenced local settlement history. The resulting revised chronology and depositional units confirm and refine prior interpretation of the local archaeological settlement history. New geomorphological data on coastal environmental change and post-depositional modification of the Cape Krusenstern beach ridge system also provide information about patterns of archaeological site preservation, indicating periods of potentially poorer site preservation around 3990 cal BP; this informs interpretation of forager settlement data. Furthermore, our findings suggest that climate-driven changes in the coastal environment at Cape Krusenstern may not be as determinative in terms of landscape evolution as previously thought. Future work should focus on further investigating the relationship between beach ridge development and regional climatic patterns on a regional scale, as this has implications for use of beach ridges as a mid-late Holocene climate proxy. Continued efforts to build paleoenvironmental reconstructions of higher temporal and spatial resolution for the region will help address remaining questions about the relationship between local coastal environmental changes and regional patterns, and the impacts of these environmental shifts on local residents.
\end{abstract}

Keywords: Human-environment interactions, Coastal paleoenvironments, Geomorphology, Maritime foragers, Chronology, Arctic 


\subsection{Introduction}

High latitude environments present challenges to human adaptive strategies. This is particularly the case during periods of increased environmental variability or unpredictability when low biodiversity and a tendency towards boom and bust cycles of resource abundance are exaggerated (Rowley-Conwy, 1999). Over the course of human history foragers expanded into and retracted from high latitudes, partially in response to environmental changes that outpaced human adaptive strategies. Humans occupied northern Asia between 40,000 and 28,000 cal BP, but abandoned the coldest regions during the Last Glacial Maximum around 24,000 to 21,000 cal BP when ice sheets were at their maximum (Clark et al. 2009; Hoffecker and Elias, 2003; Graf, 2009; but see Kuzmin and Keates, 2018). Archaeologists point to the role of environmental change in waves of mid-late Holocene human migration across the Arctic (McGhee, 2000; 2009; Morrison, 2009; but see Friesen and Arnold, 2008) and as a factor in the dramatic shifts in technology and socio-political organization during the same time period (Giddings and Anderson 1986; Gerlach and Mason 1992; Mason and Gerlach 1995a, b; Mason and Barber 2003). The variable mid-late Holocene environment of the western Arctic likely played a significant role in the development and expansion of Arctic maritime cultures over the last 4500 or more years (e.g. Mason and Gerlach 1995a,b; Mason 1998; Mason and Jordan 2002; Mason and Barber 2003; Dixon 2003), particularly when coupled with other social and political forces of change. This paper integrates paleoenvironmental, archaeological, and geomorphological data in order to advance our understanding of the relationship between cultural and environmental change during the mid-late Holocene in northwest Alaska.

In northwest Alaska, previous archaeological and paleoenvironmental research at the Cape Krusenstern (CAKR) site complex (Figures 1 and 2) (Anderson, 1962; Giddings, 1966; Moore, 1966; Giddings and Anderson, 1986; Mason and Ludwig, 1990; Mason and Jordan, 1993; McClenahan and Gibson, 1990; McClenahan, 1993;) established a framework for studying the relationship between coastal environmental change and the emergence of Arctic maritime cultures over the last 4500 years. Further understanding of human-environment interactions, however, hinges on the development of archaeological and paleoenvironmental chronologies with higher spatial and temporal resolution. Arctic paleoenvironmental proxies of suitable resolution for comparison with the archaeological record are still rare (see Kaufman et al. 2016 for a recent synthesis).

Better understanding the environmental context for significant cultural events and resolving issues of temporal resolution between geomorphological and cultural data will help archaeologists identify driving factors in cultural change. We undertook renewed research at the CAKR site complex with the purpose of 1 ) developing higher resolution archaeological and paleoenvironmental chronologies, 2) re-evaluating the local settlement history, and 3) refining the local paleoenvironmental reconstruction and landscape history. The goal of this paper is to synthesize new geomorphological and archaeological data with prior results (Anderson and Freeburg, 2013; 2014), to refine local cultural and paleoenvironmental chronologies, and to consider the question of how local environmental change may have influenced local and regional settlement history. It is not our intent to develop a revised synthesis of regional beach ridge chronologies or the Chukchi Sea paleo-storm record. Such a synthesis requires additional data and integration with research on other regional beach ridge systems (e.g. Kotzebue (Rinck and Mason 2015), Cape Espenberg (Alix et al. 2018)). Here we focus specifically on our research at Cape Krusenstern, updating and refining previous research results on this system. 


\subsection{Cultural and Environmental Context}

\subsection{Geologic Background}

The CAKR site complex is located on a series of beach ridges that began forming soon after regional sea level stabilized around 5000-6000 years ago (Mason and Jordan, 1993; 2002). The CAKR beach ridge system is one of many in the region that developed during this time period, although CAKR is one of the largest and oldest systems. The area currently occupied by CAKR was open-ocean prior to the initial deposition and stabilization above sea-level of sandy gravel beaches that anchored the subsequent accretion of more than 100 ridge-and-swale sets. The erosion and reworking of near-shore shelf sediments and mainland bluffs provided material for transport and deposition as spits, barrier islands, and eventually the broader landform of the cape. The primary direction of sediment transport along the CAKR coast during the mid-late Holocene was north to south to east, resulting in the distinctive pattern of northwest to southeast to east-trending spits that amalgamated over time to form the CAKR beach ridge complex. The down-drift ends of these spits are conspicuous between the southeast corner of Krusenstern Lagoon and the lower Tukrok River (Figure 2), which drains the lagoon through a tidally-influenced wetland to the ocean. The process of beach ridge/spit amalgamation or welding has been dynamic throughout the history of the Cape, punctuated by periods of marked erosion along segments of the shoreface, and resulting in slight reorientations of the shoreline, which have demarked spatially coherent sets of beach ridges that comprise the complex. The seaward progradation of beach ridges was relatively rapid between 5000 and $3000 \mathrm{cal} \mathrm{BP}$, marked by wide, low-elevation ridges separated by swales of roughly the same width. This morphology indicates a relatively quiescent marine climate, due either to a low frequency and/or magnitude of coastal storms, limited fetch due to extensive sea ice, or limited sediment supply. The point of origin of these ridges is now below sea level seaward of the mainland coast at the northwest corner of the CAKR complex. Shifts in storm intensity and direction, or interruptions of sediment supply, caused reworking and reorientation of the shoreline (Moore, 1960; 1966; Hopkins, 1977; Mason and Ludwig, 1990; Mason et al., 1995). Secular (e.g. shortterm, days to weeks) shifts in wind direction, storminess, and storm surges can have a significant impact on short and long term local processes of coastal sedimentation and erosion, more so than eustasy or seismic events in this region (Hume and Shalk, 1967; Mason and Jordan, 1993; Mason et al., 1995; Jordan and Mason, 1999; Mason and Jordan 2002). As such, the ridge system is thought to be a record of both average conditions reflected in ridge topography and geomorphology as well as brief, large magnitude events that led to rapid erosion and realignment of subsequent ridges.

A shift in depositional regime is conspicuous after about $2100 \mathrm{cal}$ BP and is marked by more closely-spaced, higher-elevation ridges with more variable along- and across-ridge topography. These post-2100 cal BP ridges can be broken into at least three deposition/erosion phases, but are readily distinguished from the older ridge sets by their hydrological setting: ridges that formed before about 2100 cal BP are commonly broken by lakes that have filled and flooded inter-ridge swales, or by lakes that have expanded across ridge sets via ice-push processes during spring and wave action during summer. This gross difference between depositional processes could be due to an abundance of sediment available for longshore transport and deposition at CAKR (increased coastal erosion and/or sediment delivery to the coast via streams updrift), a more energetic coastal storm climate and/or extensive fetch (at least episodically), or a further reduction in the rate of sea level rise (cf. Goodwin, 2005). During the past ca. 1000 years, sediment deposition has mostly occurred along the west and southwest reaches of the CAKR shoreline, south of the narrow barrier beach that separates the shore of Krusenstern Lagoon from the ocean, to Sealing Point, and southwest for about $6 \mathrm{~km}$ to the east-trending inflection in the coast. This has resulted in the addition of ridge-and-swale sets parallel to the modern 
shore, and most obviously, in the transport of sediment east toward Sisualik; over this time period the mouth of the Tukrok River has been diverted about $7 \mathrm{~km}$ to the east (Figures 1 and 2).

The progradational beach formation processes at CAKR formed a "horizontal stratigraphy" (Giddings, 1967)(Figure 3) that was particularly important for establishing the local and regional chronology of mid-late Holocene Arctic forager lifeways before radiocarbon dating was widely applied in archaeology. Giddings $(1966,1967)$ and others (Hopkins, 1977; Giddings and Anderson, 1986) built on Moore's research (Moore, 1960; 1966) on regional geological processes to understand the geomorphological sequence at CAKR. Giddings defined beach ridge segments based on geomorphological and archaeological evidence (Giddings 1966; Giddings and Anderson 1986); these ridge segments were later refined by Mason and Ludwig (1990) and combined with similar data from other ridge systems around the region into a regional storminess record (Mason and Jordan 1993; Mason et al. 1995; Jordan and Mason 1999). Conspicuous reorientations in the beach ridge system coincide with significant shifts in human settlement and subsistence patterns; this led researchers to hypothesize causal relationships between environmental and social changes in this region (see further discussion in section 2.2 and 2.3 ).

\subsection{Archaeological Background}

The earliest sites at CAKR are a record of the earliest known Arctic coastal lifeways, although older coastal sites could be underwater. The site complex was continuously occupied for the last 45005000 years (Giddings and Anderson, 1986; Anderson and Freeburg, 2013, 2014). Renewed research at CAKR began in 2006, with the purpose of further exploring the role coastal environmental change may have played in human settlement patterns during the mid-late Holocene period. Through a program of systematic archaeological survey, testing, and radiocarbon dating we refined the local archaeological chronology (Anderson and Freeburg, 2013) and settlement history (Anderson and Freeburg, 2014), which parallel regional reconstructions of past coastal lifeways (Schaaf, 1988; Harritt, 1994; Mason, 1998)(Table 1). The earliest sites at CAKR, dating to between about 2750 and 4500 years ago, are limited to small campsites thought to be associated with spring sealing activities (Table 1). Over time, the local population/occupation density increased, with a significant shift towards semi-permanent coastal occupation beginning around $2000 \mathrm{cal}$ BP and rapid population growth beginning around 1000 cal BP. Occupation of the site complex continued to increase until about 550 cal BP when, locally and regionally, there appears to have been a population decline or redistribution (Anderson and Freeburg, 2014; Anderson et al., in review). 
Table 1. Summary of northwest Alaskan settlement patterns (adapted from Mason, 2009b).

\begin{tabular}{|c|c|c|c|}
\hline $\begin{array}{l}\text { Archaeological } \\
\text { Culture }\end{array}$ & $\begin{array}{l}\text { Approximate } \\
\text { Age Range } \\
\text { (cal BP) }\end{array}$ & Geographic Distribution & Settlement Pattern \\
\hline Denbigh & $4500-2750$ & Kotzebue Sound, Brooks Range & $\begin{array}{l}\text { Highly mobile, seasonal } \\
\text { movement between coast and } \\
\text { interior }\end{array}$ \\
\hline Choris & $2750-2450$ & $\begin{array}{l}\text { Kotzebue Sound, Brooks Range, } \\
\text { Northern Yukon Territory }\end{array}$ & $\begin{array}{l}\text { Highly mobile, but longer } \\
\text { seasonal occupation of coastal } \\
\text { areas indicated by construction } \\
\text { of semi-subterranean houses } \\
\text { on coasts. }\end{array}$ \\
\hline $\begin{array}{l}\text { Norton (Norton- } \\
\text { Near Ipiutak in } \\
\text { Northwest Alaska) }\end{array}$ & $2500-2000$ & $\begin{array}{l}\text { Southern AK Peninsula to } \\
\text { Western Canada, unknown in } \\
\text { Siberia and Chukotka }\end{array}$ & $\begin{array}{l}\text { Possible reduced residential } \\
\text { mobility. Few northwest } \\
\text { Alaskan sites dated to this time } \\
\text { period; period poorly } \\
\text { understood }\end{array}$ \\
\hline Ipiutak & $1750-1150$ & $\begin{array}{l}\text { Norton Sound to Point Barrow, } \\
\text { interior of Northwest Alaska } \\
\text { and Brooks Range }\end{array}$ & $\begin{array}{l}\text { Reduced residential mobility } \\
\text { with longer occupation of } \\
\text { coasts on a seasonal basis. } \\
\text { Increase in coastal settlement } \\
\text { size. }\end{array}$ \\
\hline Birnirk & $1350-750$ & $\begin{array}{l}\text { Eastern and western shores of } \\
\text { Chukchi sea }\end{array}$ & $\begin{array}{l}\text { Reduced residential mobility } \\
\text { with longer occupation of } \\
\text { coasts on a seasonal basis. } \\
\text { Increase in coastal settlement } \\
\text { size. Note that there are only a } \\
\text { few sites attributed to Birnirk } \\
\text { culture in northwest Alaska. }\end{array}$ \\
\hline Thule & $950-550$ & Bering Strait to Greenland & $\begin{array}{l}\text { Semi-permanent occupation of } \\
\text { coastal areas. Large coastal } \\
\text { settlements. }\end{array}$ \\
\hline $\begin{array}{l}\text { Late } \\
\text { Thule/Kotzebue } \\
\text { (Arctic Woodland } \\
\text { in interior areas of } \\
\text { Northwest Alaska) }\end{array}$ & $550-250$ & $\begin{array}{l}\text { Coastal and inland areas of } \\
\text { Northwest Alaska }\end{array}$ & $\begin{array}{l}\text { Semi-permanent occupation of } \\
\text { coastal areas. Possible increase } \\
\text { in logistical mobility. Smaller } \\
\text { settlements than preceding } \\
\text { period, occupations shift to } \\
\text { previously unoccupied } \\
\text { locations. Interior settlements } \\
\text { smaller than contemporary } \\
\text { coastal occupations. }\end{array}$ \\
\hline
\end{tabular}

\subsection{Northwest Alaska Paleoenvironmental Record}

Paleoenvironmental proxies indicate that the regional climate, particularly over the last 1500 years (see overviews in Jordan, 2009; Kaufman et al., 2016; Mason 2009a), was highly variable in northwest Alaska, however, the timing and impacts of the Medieval Climate Anomaly (MCA ca. 1000$700 \mathrm{BP}$ ) and the Little Ice Age (LIA ca. 600-100 BP) are not consistently apparent in proxy records. The 
regional paleoenvironmental dataset is relatively coarse both temporally and spatially and does not reflect differences in coastal versus interior environments and associated subsistence strategies. Subregional differences in the timing and character of environmental variability are known but not well understood. A systematic review of multiple Holocene climate proxies for northwest Alaska (Kaufman et al. 2016) indicates maximum mean annual regional temperatures between 7000 - 5000 BP (e.g., midge proxies indicate July temperatures were $0.2^{\circ} \mathrm{C}$ higher than the most recent millennium) and decreasing average temperatures after 3000-4000 cal BP. However, high-resolution sea-ice reconstructions in the same region of the Chukchi Sea "show no strong agreement other than a general lack of an overall trend during the Holocene" (Kaufman et al. 2016:318).

At a regional level, the cultural changes described above are often attributed at least in part to shifts in the mid-late Holocene environment (e.g. Anderson, 1984; Giddings and Anderson, 1986; Minc and Smith, 1989; Mason and Gerlach, 1995a; 1995b; Mason, 1998; Mason and Jordan, 2002; Dixon, 2003; Mason and Barber, 2003; Murray et al., 2003). For example, environmental variability is often proposed as the driver behind the migration of people into Northwest Alaska around 4500 years ago and again around 1300-1500 years ago (Mason and Gerlach, 1995a,b ; Tremayne and Winterhalder, 2017). Variability in one part of the region (e.g. eastern Beringia) may have pushed people to seek out new, better or more stable resources in another part of the region (e.g. western Beringia/northwest Alaska), or to explore alternative resource procurement strategies and technologies (e.g. Minc and Smith, 1989; Tremayne and Winterhalder, 2017). The adoption of whaling and the later shift to open water whale hunting during the last 1500 years is frequently linked to environmental changes that made whales more available to coastal hunters (e.g. Dixon, 2003; Mason and Barber, 2003). Changes in settlement patterns and subsistence after 550 cal BP are thought by some to be related to climatically driven cessation in whaling activities (Giddings and Anderson, 1986; Harritt, 1994), but are also attributed to the adoption of dog traction (Hall, 1978), or a function of increased social interaction with a broader socio-political sphere (Mason, 1998). Or, perhaps post-500 cal BP settlement and subsistence changes could have been a more general response to increased environmental variability in the Late Holocene.

However, inconsistencies among paleoenvironmental proxies and interpretation of climate conditions from proxies leads to opposing archaeological narratives. For instance, some (Taylor, 1963; Bockstoce, 1973; McGhee, 2000) have suggested that Thule cultural development expansion was linked to a warmer climate and less sea ice that allowed for increased returns on marine mammal foraging. In contrast, Mason and Barber (2003) argue that cold and stormy conditions increased marine productivity and caused the Thule expansion. Refined dating for Thule occupation of the western Canadian Arctic (Friesen and Arnold, 2008) calls into question the relationship between the Thule migration and climatic events in general. The lack of finer-scale paleoenvironmental data is particularly challenging for archaeologists studying seasonally or logistically mobile groups such as those of pre-Euro-American contact northwest Alaska; multiple proxies must be considered to understand human adaptation to localized environmental differences (e.g. use of coastal versus interior environments).

To explore this at CAKR, we focus on local proxy data from the beach ridge complex as the highest resolution, most geographically proximate record of environmental conditions. The need for higher resolution environmental data guided geomorphological field work at CAKR; sampling was designed to look more specifically at changes in storm intensity, sediment supply, and relative sea level in order to refine the existing framework established by prior geomorphological and paleoecological research on Kotzebue Sound beach ridge systems (e.g. Mason and Jordan, 1993; 1997; 2002; Mason et al., 1995; 1997). 


\subsection{Methods and Field Activities}

\subsection{Archaeological}

Four years of fieldwork were conducted at CAKR, beginning in 2006 and from 2008-2010. Field methods included pedestrian survey and sample collection as well as precise mapping of archaeological and environmental features across the beach ridge complex. We systematically and intensively surveyed areas of the beach ridge system and conducted sub-surface testing in areas of where the ground surface was covered with vegetation. We also selectively sampled surface depressions and vegetation anomalies (patches of dense vegetation different from surrounding vegetation) we considered potentially indicative of archaeological deposits. Larger excavations, up to 3 by $3 \mathrm{~m}$ in size, focused on archaeological features for sample collection purposes. We relocated previously recorded sites and collected new samples for dating and other analyses from these locations, and sampled sites on cultural and non-cultural features on different depositional units (see Anderson and Freeburg 2013; Freeburg and Anderson 2012 for additional survey details).

We surveyed approximately 1,205 hectares (36\%) of the 3,300 hectare beach ridge complex and identified a total of 1,377 archaeological features, including both new and previously recorded features. We obtained a total of 239 new radiocarbon dates from archaeological contexts; 151 dates were published previously (Anderson and Freeburg, 2013, 2014) and 88 new dates are presented here for the first time (Supplemental Table 1). Conventional radiocarbon dates were calibrated using IntCal13 and Marine13 (Reimer et al., 2013) calibration curves in OxCal 4.3.2 (Ramsey, 2009).

\subsection{Geomorphological}

Geomorphological research, conducted in 2008 and 2009, was focused on refining our knowledge of the physical evolution of the CAKR beach ridge complex. Fieldwork focused on mapping boundaries between distinct ridge sets and obtaining non-cultural organic samples to refine a chronostratigraphy of the complex that is independent of, yet augments, the cultural chronology. Prior geomorphological study of the ridge system relied solely on archaeological dates to provide limiting ages for the ridges themselves (e.g. Mason and Jordan 1993). Specific survey and reconnaissance areas were prioritized based on analysis of aerial photographs, the literature relevant to the geomorphological history of the complex, and gaps or uncertainties identified in the dating of the complex. Areas of focus included the eastern quadrant of the CAKR beach ridge complex where the ridges terminate in ponds or marshes defined by Krusenstern Lagoon and the Tukrok wetlands, as well as the north and west margin of the complex at Krusenstern Lagoon (Figure 2).

A total of 43 non-cultural sites were examined during geomorphological survey of the beach ridge complex; contexts included beach ridge crests, swales between beach ridges, marshes, peat lands, and natural erosion exposures. Forty-three organic samples (driftwood fragments, peat, silty peat, organic silt) were collected with trowel from shovel test pit walls, from cores obtained with an Oakfield or Gouge corer, and from natural exposures. Twenty-five of these samples were submitted for radiocarbon analyses. Eight additional non-cultural organic samples were collected during the course of archaeological shovel testing; these were wood fragments of conifer (some identifiable as Picea) that probably were deposited as pieces of driftwood on the upper shoreface or in overwash deposits in swales behind the seaward-most beach (Table 2). Conventional radiocarbon dates were calibrated using IntCal13 and Marine13 (Reimer et al., 2013) calibration curves in OxCal 4.3.2 (Ramsey, 2009). 
Table 2. Geomorphological Ages. See Figure 4 and Supplemental Table 2 for Sample Location. Conventional radiocarbon dates were calibrated using IntCal13 and Marine13 (Reimer et al., 2013) calibration curves in OxCal 4.3.2 (Ramsey, 2009).

\begin{tabular}{|c|c|c|c|c|c|c|c|}
\hline Lab\# & Field Number & $\begin{array}{c}\text { Beach } \\
\text { Segments }\end{array}$ & $\begin{array}{c}\text { Conventional } \\
\text { Age (BP) }\end{array}$ & $\begin{array}{c}\text { Two o } \\
\text { Calibrated Age } \\
\text { (cal BP) }\end{array}$ & $\begin{array}{c}\text { Material } \\
\text { Dated }\end{array}$ & Sample Context & $\begin{array}{l}\text { Depth of } \\
\text { Sample } \\
\text { (cm Below } \\
\text { Surface) }\end{array}$ \\
\hline $\begin{array}{l}\text { Beta } \\
254651\end{array}$ & 08-CK-4-4 & I & $102.5 \pm 0$ & Modern & Peat & $\begin{array}{l}\text { Sample collected from inter-ridge } \\
\text { swale peat exposed on lake } \\
\text { cutbank ca. } 300 \mathrm{~m} \text { e of } 09-\mathrm{CK}-2\end{array}$ & $3-4 \mathrm{~cm}$ \\
\hline $\begin{array}{l}\text { Beta } \\
255139\end{array}$ & 08-CK-10-9 & I & $101.9 \pm 0$ & Modern & Peat & $\begin{array}{l}\text { Core collected on potentially } \\
\text { second oldest ridge/swale set in } \\
\text { complex, NW corner of } \\
\text { Krusenstern Lagoon }\end{array}$ & $8-9 \mathrm{~cm}$ \\
\hline $\begin{array}{l}\text { Beta } \\
255142\end{array}$ & 08-CK-10-55 & I & $500 \pm 40$ & 631 to 495 & Peat & $\begin{array}{l}\text { Core in peat on potentially second } \\
\text { oldest ridge/swale set in complex, } \\
\text { NW corner of Krusenstern Lagoon }\end{array}$ & $54-55 \mathrm{~cm}$ \\
\hline $\begin{array}{l}\text { Beta } \\
255140\end{array}$ & 08-CK-10-24 & I & $520 \pm 50$ & 647 to 498 & Peat & $\begin{array}{l}\text { Core in peat on potentially second } \\
\text { oldest ridge/swale set in complex, } \\
\text { NW corner of Krusenstern Lagoon }\end{array}$ & $23-24 \mathrm{~cm}$ \\
\hline $\begin{array}{l}\text { Beta } \\
255141\end{array}$ & 08-CK-10-29 & I & $570 \pm 40$ & 652 to 522 & Peat & $\begin{array}{l}\text { Core in peat on potentially second } \\
\text { oldest ridge/swale set in complex, } \\
\text { NW corner of Krusenstern Lagoon }\end{array}$ & $28-29 \mathrm{~cm}$ \\
\hline $\begin{array}{l}\text { Beta } \\
254652\end{array}$ & 08-CK-4-18 & I & $1060 \pm 40$ & 1059 to 922 & Peat & $\begin{array}{l}\text { Collected from inter-ridge swale } \\
\text { peat exposed on lake cutbank ca. } \\
300 \mathrm{~m} \text { east of } 09-\mathrm{CK}-2\end{array}$ & $17-18 \mathrm{~cm}$ \\
\hline $\begin{array}{l}\text { Beta } \\
256625\end{array}$ & 08-CK-11 & I & $1730 \pm 40$ & 1730 to 1545 & Peat & $\begin{array}{l}\text { Peat core collected at SW corner } \\
\text { of largest lake connected to } \\
\text { Krusenstern Lagoon }\end{array}$ & $37-38 \mathrm{~cm}$ \\
\hline $\begin{array}{l}\text { Beta } \\
317990\end{array}$ & 09-CK-14-20 & I & $1820 \pm 30$ & 1860 to 1630 & Organic silt & $\begin{array}{l}\text { Core sample collected at relict } \\
\text { lake-end ridge at E end of large } \\
\text { rectangular lake open to } \\
\text { Krusenstern Lagoon, NW sector of } \\
\text { complex }\end{array}$ & $19-20 \mathrm{~cm}$ \\
\hline $\begin{array}{l}\text { Beta } \\
256626\end{array}$ & 08-CK-13 & I & $1800 \pm 50$ & 1865 to 1605 & Peat & $\begin{array}{l}\text { Collected from inter-ridge swale } \\
\text { peat exposed on shore of } \\
\text { Krusenstern Lagoon }\end{array}$ & $9-11 \mathrm{~cm}$ \\
\hline Beta & 09-CK-14-30 & I & $2150 \pm 30$ & 2305 to 2010 & Organic silt & Core collected at relict lake-end & $29-30 \mathrm{~cm}$ \\
\hline
\end{tabular}

Page $\mathbf{9}$ of $\mathbf{3 0}$

(c) 2018. This manuscript version is made available under the CC-BY-NC-ND 4.0 license http://creativecommons.org/licenses/by-nc-nd/4.0/ 
Krusenstern Lagoon, NW sector of complex

\begin{tabular}{|c|c|c|c|c|c|c|c|}
\hline & & & & & & & \\
\hline $\begin{array}{l}\text { Beta } \\
256627\end{array}$ & $08-\mathrm{CK}-22$ & I & $3250 \pm 40$ & 3566 to 3389 & Peat & $\begin{array}{l}\text { Peat in swale at north side of Old } \\
\text { Whaling ridge, at SE end of large } \\
\text { elongate lake }\end{array}$ & $20-21 \mathrm{~cm}$ \\
\hline $\begin{array}{l}\text { Beta } \\
256852\end{array}$ & $08-C K-4-22$ & I & $3280 \pm 40$ & 3607 to 3402 & Peat & $\begin{array}{l}\text { Inter-ridge swale peat exposed on } \\
\text { lake cutbank ca. } 300 \mathrm{~m} \text { east of 09- } \\
\text { CK-2 }\end{array}$ & $21-22 \mathrm{~cm}$ \\
\hline $\begin{array}{l}\text { Beta } \\
277795\end{array}$ & 09-CK-3 & I & $4060 \pm 40$ & 4802 to 4425 & $\begin{array}{l}\text { Driftwood } \\
\text { fragment }\end{array}$ & $\begin{array}{l}\text { Shovel test at Krusenstern Lagoon } \\
\text { camp, 1st ridge from lagoon }\end{array}$ & $78-79 \mathrm{~cm}$ \\
\hline $\begin{array}{l}\text { Beta } \\
255668\end{array}$ & 08-CK-8-49 & Ila & $2310 \pm 40$ & 2431 to 2158 & Peat & $\begin{array}{l}\text { Sample collected from inter-ridge } \\
\text { swale peat exposed on second } \\
\text { lake system S of E end of } \\
\text { Krusenstern Lagoon }\end{array}$ & $48-49 \mathrm{~cm}$ \\
\hline $\begin{array}{l}\text { Beta } \\
255669\end{array}$ & 08-CK-8-61 & Ila & $2680 \pm 40$ & 2857 to 2746 & Peat & $\begin{array}{l}\text { Sample collected from inter-ridge } \\
\text { swale peat exposed on second } \\
\text { lake system } \mathrm{S} \text { of } \mathrm{E} \text { end of } \\
\text { Krusenstern Lagoon }\end{array}$ & $60-61 \mathrm{~cm}$ \\
\hline $\begin{array}{l}\text { Beta } \\
256629\end{array}$ & $08-\mathrm{CK}-24$ & III & $2200 \pm 40$ & 2330 to 2120 & Peat & $\begin{array}{l}\text { Core collected from peat in swale } \\
\text { ca. } 300 \mathrm{~m} \text { SE of } 08-C K-24 \text {, five } \\
\text { ridges } \mathrm{N} \text { of Old Whaling ridge }\end{array}$ & $27-28 \mathrm{~cm}$ \\
\hline OS-94052 & CAKR09-0214 & III & $2460 \pm 25$ & 2705 to 2379 & $\begin{array}{c}\text { Wood } \\
\text { charcoal }\end{array}$ & Shovel test in beach ridge & $11 \mathrm{~cm}$ \\
\hline $\begin{array}{l}\text { Beta } \\
317989\end{array}$ & 09-CK-7 & III & $2940 \pm 30$ & 3206 to 2993 & Organic silt & $\begin{array}{l}\text { Shovel test on second ridge S of } \\
\text { 'amalgamated lake' at head of } \\
\text { ridge bifurcation, varved } \\
\text { sediment }\end{array}$ & $64-65 \mathrm{~cm}$ \\
\hline $\begin{array}{l}\text { Beta } \\
256628\end{array}$ & $08-C K-23$ & IV & $630 \pm 40$ & 665 to 549 & Peat & $\begin{array}{l}\text { Core collected in peat in swale at } \\
\mathrm{S} \text { end of } \mathrm{N}-\mathrm{S} \text { elongate lake } \\
\text { dammed by ridges } 4-5\end{array}$ & $18-19 \mathrm{~cm}$ \\
\hline OS-94135 & CAKR09-0354 & IV & $2400 \pm 25$ & 2677 to 2350 & & & \\
\hline $\begin{array}{l}\text { Beta } \\
256853\end{array}$ & $08-\mathrm{CK}-26$ & IV & $2390 \pm 40$ & 2696 to 2338 & Peat & $\begin{array}{l}\text { Core collected in peat in swale } \\
\text { one ridge } \mathrm{S} \text { of } \mathrm{S} \text { shore of irregular } \\
\text { lake }\end{array}$ & $28-29 \mathrm{~cm}$ \\
\hline Beta & 09-CK-16 & $\mathrm{V}$ & $170 \pm 30$ & 291 to Modern & Silty peat & Shovel test in shallow swale in & $9-10 \mathrm{~cm}$ \\
\hline
\end{tabular}




\begin{tabular}{|c|c|c|c|c|c|c|c|}
\hline $\begin{array}{l}\text { Beta } \\
317987\end{array}$ & 09-CK-1 & V & $850 \pm 30$ & 898 to 690 & Peat & $\begin{array}{l}\text { Shovel test in peat at head of } \\
\text { swale }\end{array}$ & $18-19 \mathrm{~cm}$ \\
\hline $\begin{array}{l}\text { Beta } \\
317988\end{array}$ & 09-CK-2 & $\mathrm{V}$ & $960 \pm 30$ & 930 to 795 & Silty peat & $\begin{array}{l}\text { Shovel test in prominent swale } \\
\text { (third from shore), basal peat }\end{array}$ & $15-16 \mathrm{~cm}$ \\
\hline OS-94113 & CAKR08-0259 & $\mathrm{V}$ & $1630 \pm 25$ & 1603 to 1416 & Wood & Shovel test in beach ridge & $38 \mathrm{~cm}$ \\
\hline OS-94134 & CAKR09-0267 & $\mathrm{V}$ & $1860 \pm 25$ & 1868 to 1724 & Wood & Shovel test in beach ridge & $43 \mathrm{~cm}$ \\
\hline OS-94053 & CAKR09-0264 & V & $1920 \pm 30$ & 1948 to 1746 & Wood & Shovel test in beach ridge & $45 \mathrm{~cm}$ \\
\hline $\begin{array}{l}\text { Beta } \\
317993\end{array}$ & 09-CK-17 & V & $1920 \pm 40$ & 1968 to 1736 & Peat & $\begin{array}{l}\text { Shovel test at west end of narrow } \\
\text { swale lake, Fibric peat }\end{array}$ & $19-22 \mathrm{~cm}$ \\
\hline OS-94153 & CAKR09-0285 & $\mathrm{V}$ & $1950 \pm 30$ & 1970 to 1825 & Wood & Shovel test in beach ridge & $48-51 \mathrm{~cm}$ \\
\hline OS-94054 & CAKR10-0024 & $\mathrm{VIb}$ & $355 \pm 35$ & 497 to 315 & Wood & $\begin{array}{l}\text { Shovel test in beach ridge. Just } \\
\text { below sod layer. }\end{array}$ & $42 \mathrm{~cm}$ \\
\hline OS-94384 & CAKR10-0352 & $\mathrm{VIb}$ & $900 \pm 30$ & 911 to 741 & Wood & Shovel test in beach ridge. & $42-46 \mathrm{~cm}$ \\
\hline $\begin{array}{l}\text { Beta } \\
255143\end{array}$ & 08-CK-15-37 & $\mathrm{n} / \mathrm{a} *$ & $990 \pm 40$ & 965 to 795 & Peat & $\begin{array}{l}\text { Peat and silty peat exposed along } \\
\text { low bluff } 75 \mathrm{~m} \text { S of } 09-\mathrm{CK}-14\end{array}$ & $37-38 \mathrm{~cm}$ \\
\hline $\begin{array}{l}\text { Beta } \\
255144\end{array}$ & $08-C K-14-127$ & $\mathrm{n} / \mathrm{a} *$ & $5850 \pm 50$ & 6784 to 6507 & Peat & $\begin{array}{l}\text { Peat core at NW shore of largest } \\
\text { of three lakes E of Tukrok River }\end{array}$ & $\begin{array}{c}126-127 \\
\mathrm{~cm}\end{array}$ \\
\hline
\end{tabular}

*Dates obtained SE of beach ridge complex in Tukrok Wetlands, not directly associated with a beach ridge set. 


\subsection{Results}

\subsection{Cape Krusenstern Depositional Units}

Since the onset of beach ridge deposition after $6000 \mathrm{cal}$ BP, at least six distinct sets of beach ridges have been deposited (Moore and Giddings, 1961; Moore, 1966; Zimmerman, 1981; Mason and Ludwig, 1990). The differentiations between which are recognized by reorientations of set alignments, minor differences in the elevation of sets, and in some cases, erosional truncations. Both geological and archaeological conventions for noting the relative ages of these horizontal units are presented here. Our updated scheme uses the geological convention, in which the oldest unit is indicated as "I", with successively younger units being noted as II, III, IV, etc. (Figure 4 and 5); in this scheme future units can be added as new ridge sets develop along the coast. This is in contradiction to the past archaeological designation convention at CAKR, in which the oldest unit was designated with the highest number (VI)(see Figure 3).

The results of radiocarbon analyses of organic samples obtained from non-cultural contexts at CAKR are summarized in Table 2 . The maximum-limiting ages are generally consistent with previous studies (Mason and Ludwig, 1990; Mason et al., 1995). Some minimum-limiting ages are inconsistent with those obtained from archaeological contexts (i.e. Unit Ii, III, and V). This could be due to inadvertent dating of old wood from archaeological contexts or inadequate geologic sampling. Based on geomorphological data and dating of non-cultural organic samples obtained during this research, we define six primary depositional units at CAKR. See section 5.3 for additional discussion.

Unit I. This unit is characterized by the development of linear and narrow rectangular lakes that have filled and expanded from swales between ridges, drowning many ridges (especially in the western half of the unit), by ice-wedge development and melting, and permafrost degradation. Beach ridges are slightly lower-lying than those in younger units (Figure 6), the water table is relatively high, and swales are wet and thickly-vegetated where they have not been flooded (Figure 5, Inset 1 and 2). Soils are welldeveloped on better-drained ridges of this unit, commonly exhibiting evidence of podsolization, indicating a long period of surface stability. The eastern limit of Unit I terminates in wetlands of the upper Tukrok River floodplain, which becomes a broad shallow lake during high water. The plan-view morphology of this unit (Figure 6), and that of the termini of its ridges, is demonstrative process of barrier spit formation that is still apparent $30 \mathrm{~km}$ downdrift (to the east of CAKR) at Sisaulik (Figures 1 and 4). Sub-unit la is defined on the basis of slight reorientations of adjacent ridges apparent on remote sensing imagery. Ages on driftwood buried in an early ridge (Beta 277795), and on buried peat from an early back barrier lagoon setting suggest that widespread ridge formation occurred after 5000 to 5500 cal BP, contemporaneous with the relative stabilization of sea level. The oldest geological date obtained during this project (Beta 255144, ca. $6600 \mathrm{cal}$ BP) was from a buried marsh peat horizon, $127 \mathrm{~cm}$ below the current marsh surface in the Tukrok Wetlands (Figure 2), indicates that sea level had reached this elevation by that time, and that overwash deposits behind incipient barrier bars or islands were supporting colonization of marsh vegetation. Radiocarbon ages from beach ridge geologic contexts indicate that this unit began forming between 3400 and 5000 cal BP (Table 2, Beta 256627, 256852, 277795). Anomalously young ages on geological samples from swales between Unit I beach ridges, and from exposures or cores along Krusenstern Lagoon in the NW sector of the complex, likely record fluctuations of the lagoon level and the associated development and burial of vegetation/peat horizons in response. 
Unit II. Unit II is primarily distinguished from Unit I by the existence and geologically-more-recent expansion of a series of large circular lakes into and across its low-lying ridges (Figure 5, Inset 3). Ridges in this unit are more discontinuous than those of Unit I and subsequent ones. They are typically lowelevation (Figure 6), with some exceptions in the eastern half of the unit, and also exhibit some cryogenic modification in the form of cross-ridge ice wedge cracks. Swales between ridges are relatively wide and wet, and linear lakes are expanding along swales and across some ridges in the east. A fragment of this unit, separated from the majority of the unit by past erosion of the shoreline, is mapped in the northwest extreme of the CAKR complex. The plan-view of this unit (Figure 6) also illustrates the barrier spit morphology preserved in Unit I and observed today at nearby Sisualik. Radiocarbon ages from geologic contexts indicate that this unit formed between 2400 and 2800 cal BP (Table 2 and 5; see Section 4.2 discussion).

Unit III. An erosional unconformity that truncates Units I and II, most conspicuously in the western half of the complex, separates Unit III from Units I and II (Figure 4). The seaward margins of the ridges that comprised Units I and II were eroded at this time, and the resulting shoreline, and subsequent ridges, were formed at an angle that was offset from the previous one. The eastern half of Unit III, like portions of Units I and II, are low-lying relative to ridges up- and down-drift, and to younger units (Figure 6). The northern, landward margin of Unit III is demarked by a line along which the southern limit of the large circular and rectangular (in the east) lakes of Unit II transitions to a set of higher and well-drained ridges occur. The eastern, distal ends of Unit III ridges have been truncated by recent wave erosion in the upper Tukrok River basin. Radiocarbon ages from geologic contexts indicate that this unit formed between 2100 and 3000 cal BP (Table 2), i.e. the age is unresolved from that of Unit II.

Unit IV. This unit marks another reorientation of the local shoreline, and is marked by the erosion of Unit III beach ridges, and a slight but topographically significant transition to a new depositional regime (Figure 4). Ridges of this unit are comparatively well-drained, more closely-spaced, and topographically higher than earlier units (Figure 5, Inset 4; Figure 6). The northern, landward, boundary of this unit marks a transition from lower-elevation and wetter ridge-swale sets to higher and more closely-spaced and better-drained ridges and swales that comprise the subsequent younger units. A fragment of this unit, separated from the majority of the unit by past erosion of the shoreline, is mapped in the northwest extreme of the CAKR complex. Radiocarbon ages from geologic contexts indicate that this unit formed between 2300 and 2700 cal BP (Table 2).

Unit $\mathrm{V}$. The formation and progradation of beach ridges in this unit marks a significant shift in the depositional regime at CAKR (Figure 4). High-elevation, closely-spaced, and well-drained ridges indicate an increased sediment supply and more rapid deposition than occurred during the development of older units (Figure 5, inset 4; Figure 6). The northern, landward boundary of this unit clearly truncates the seaward ridges of units III and IV, and the landward-most ridges of this unit are among the highest in the entire CAKR complex; only a few of the seaward-most ridges of Unit VI are equivalent in elevation. ). Like Unit I, anomalously young ages from geological samples on Unit $V$ are the result of sampling sites that record depositional events/processes that post-date ridge formation. Radiocarbon ages from geologic contexts indicate that this unit formed between 1700 and 2000 cal BP (Table 2).

Unit VI. Ridges of this unit are morphologically similar to those of Unit V but are distinguished from it by a reorientation of the coast that cut into its south and west margins (Figure 5, Inset 5). Several ridges along the west-southwest margin of Unit VI have been lost to erosion, sediments from which have been transported down-drift to the east, toward Anigaaq and Sisualik. Unit VI records relatively recent deposition and erosion; ridges are continuing to be added to the western sector of this unit. Units Vla 
and $b$ are currently differentiated on the basis of topographic differences noted in the field and now apparent on new, higher resolution spatial data of CAKR (Figures 5 and 6). Ridges in the southern portion of Unit VIb display a wavy, undulating topography that is not present in Unit Vla. The majority of this area was outside the selected archaeological survey area. However, archaeological dates from the northern boundary of Unit VIb range from approximately 1300 to 340 cal BP (bracketing ages from OS-78456 and OS-81645, Supplemental Table 1), and two geologic dates (OS-94384, OS-497315) range from approximately 911 to 315 cal BP indicating that the VIb landscape may have formed very rapidly during the last several centuries, perhaps during a period of different or fluctuating depositional conditions. This could be associated with LIA influence on coastal change, but additional fieldwork and dates are needed to explore this hypothesis. There are no geologic ages for Unit Vla; archaeological ages range from $730 \mathrm{cal} \mathrm{BP}$ to the modern era; the samples collected closest to the V/VI boundary date to 514-316 cal BP (Beta 2266692) and 470-152 (Beta 223219). Radiocarbon ages from geologic contexts indicate that Unit VI formed during the past 1300 years (Table 2 ).

\subsection{Archaeological and Geological Units and Chronology}

Dating the evolution of the CAKR beach ridge system is more difficult than originally conceived. Since the onset of geological and archaeological investigations of CAKR in the 1950s and '60s, there has been general agreement about the delimitations of depositional unit boundaries. As higher-resolution topographic, geomorphological, and chronological data become available our ability to distinguish discrete depositional units and sub-units has increased. However, these details have led us to a greater understanding of the complexities over time and space of shoreline sedimentation in mixed sand and gravel systems; our goal is to refine some of the broader generalizations made about how and when these systems formed.

We now know that many, if not all, of the beach ridges at CAKR are composite ridges and are not always precise time-stratigraphic indicators. They mark the location of a shoreline over time scales ranging from days to years to decades, and as such they built up vertically by (and are composites of) periodic or episodic delivery of sediment to their surface and to seaward and landward faces by tides, waves and storms of varying magnitude (cf. Orford 1987, Orford et al. 1995, Anthony 2009). Their internal stratigraphy records such fluctuations of wave energy, resulting in stacked deposits of varying grain size. In some cases, younger beaches can migrate landward during individual or consecutive storms, burying swales and lower ridges or ridge segments, resulting in a palimpsest. Ridges may also bifurcate or coalesce along-shore, depending on wave energy and direction and small variations in sediment supply. Therefore, the boundaries defined between units may mark processes that occurred over varying periods of time. We came to a similar conclusion about the dating of archaeo-stratigraphic units (Anderson and Freeburg, 2013, 2014). This is especially true for boundaries that are drawn between units that are not separated by an obvious erosional truncation or a significant realignment of ridge sets. For those that are, the duration of the episode of erosion that resulted in a reorientation of subsequent ridges varies with the duration of the "disturbance." A secular shift in wind and wave direction and/or wave intensity may persist for a season or two (e.g. the Bering Sea storms of 1974-75, Fathauer, 1975), for a few years, or for decades and longer; the erosion and realignment of beaches can occur across any of these time scales. The episodic starvation of sediment to the CAKR complex due the breaching of thaw lakes along the coast updrift, for example, could also result in the seaward erosion of some beach ridge sets for decades or longer (Hopkins, 1977). This finding has significance for regional paleoenvironmental interpretations and also for studying the relationship between cultural and environmental change in northwest Alaska. 
As a result of both natural and cultural processes, the relationship between previously defined beach segments from cultural contexts and the segments defined by new geomorphological work is not straightforward; while general agreement between geological and archaeological chronologies exists, there is not a one to one relationship between the data sets (Tables 3 and 4). In this paper, we shift to using the new unit designations in our discussion of how new geomorphological information and dates inform our archaeological interpretations.

This archaeological analysis adds 88 dates to the project radiocarbon database (Supplemental Table 1). Of these dates, two appear to be erroneous because they are significantly older than the CAKR landform itself (OS-93937, 10760-10566 cal BP and OS-94374, 6599-5948 cal BP). These dates are excluded from additional analysis, as is one date that yielded a modern age (Beta 326110), and one date that was obtained outside of the main beach ridge complex (OS-96755).

Analysis of the archaeological radiocarbon dates in relationship to the new beach units suggests that Units II/Ila, III, and V may be older than the geologic dating indicates (Table 4, Figure 7). It is possible that we dated old wood from the archaeological deposits, or that additional geologic dates are needed to further refine the landscape history. The majority of the newly dated samples are from Units $\mathrm{V}$ and $\mathrm{VI}$ and yielded ages from the last 2000 years (Supplemental Table 1; Figure 7). The new archaeological dates push back the maximum limiting ages for Units $\mathrm{V}$ and $\mathrm{VI}$ (previously Units I and II: Anderson and Freeburg, 2013) and further highlight the overlapping occupation of these beach segments over the last 1300 years (Tables 3 and 4, Figure 7). 
Table 3. Approximate relationship between archaeological and geological beach ridge ages (see Anderson and Freeburg, 2013).

\begin{tabular}{|c|c|c|c|c|c|}
\hline \multirow{2}{*}{$\begin{array}{c}\text { Archaeological } \\
\text { Beach } \\
\text { Segment }\end{array}$} & \multirow{2}{*}{$\begin{array}{l}\text { Geological } \\
\text { Beach } \\
\text { Segment }\end{array}$} & \multirow{2}{*}{$\begin{array}{l}\text { Pre-Project } \\
\text { Approximate } \\
\text { Age Ranges }\end{array}$} & \multicolumn{2}{|c|}{$\begin{array}{l}\text { Maximum Limiting Archaeological } \\
\text { Dates (2013) }\end{array}$} & \multirow[b]{2}{*}{$\begin{array}{c}\text { Previous Archaeological Culture } \\
\text { Attributions }{ }^{1}\end{array}$} \\
\hline & & & $\begin{array}{c}\text { Conventional } \\
\text { Radiocarbon } \\
\text { Age }\end{array}$ & $\begin{array}{c}\text { Two Sigma } \\
\text { Calibrated Age } \\
\text { Range (cal BP) }{ }^{4}\end{array}$ & \\
\hline $\mathrm{VI}$ & 1 & $\begin{array}{c}4200-3600 \\
\mathrm{BP}^{1}\end{array}$ & $3760 \pm 35$ & $4240-3990$ & Classic Denbigh \\
\hline V & Ia, II, IIa & $\begin{array}{c}3600-3100 \\
\mathrm{BP}^{1}\end{array}$ & $3620 \pm 30$ & $4070-3840$ & $\begin{array}{l}\text { Classic - Late Denbigh, Early } \\
\text { Choris }\end{array}$ \\
\hline IV & IIa, III & $\begin{array}{c}3100-2500 \\
B P^{1,2}\end{array}$ & $2930 \pm 40$ & $3210-2960$ & Old Whaling, Choris \\
\hline III & IV & $\begin{array}{c}2500-2000 \\
\mathrm{BP}^{1}\end{array}$ & $2630 \pm 25$ & $2780-2740$ & Norton-Near Ipiutak \\
\hline II & $\mathrm{V}$ & $\begin{array}{c}1900\left(1750^{3}\right)- \\
1000 \mathrm{BP}\end{array}$ & $1980 \pm 25$ & $1990-1880$ & Ipiutak, Birnirk, Thule \\
\hline I & Vla,b & $\begin{array}{c}1000- \\
\text { present }^{1}\end{array}$ & $1030 \pm 25$ & $1600-1420$ & Thule, Kotzebue, Historic Iñupiat \\
\hline
\end{tabular}

\footnotetext{
${ }^{1}$ Giddings and Anderson 1986

${ }^{2}$ Darwent and Darwent (2005) report two sigma age ranges between 3138 and 2742, but interpret the site occupation to have been between ca. 2900 and 2700 BP.

${ }^{3}$ Mason 2009

${ }^{4}$ Calibrated with OxCal 4.3.2 (Bronk Ramsey 2017) IntCal13 (Reimer et al. 2013) and Marine13 (Reimer et al. 2013).
} 
Table 4. Revised geologic and archaeological limiting ages for beach ridge units. See Section 4.1 for interpretation of geologic ages.

\begin{tabular}{cccc}
$\begin{array}{c}\text { Geological Beach } \\
\text { Segments }\end{array}$ & $\begin{array}{c}\text { New Limiting } \\
\text { Geologic Dates } \\
\text { (cal BP) }\end{array}$ & $\begin{array}{c}\text { New Maximum Limiting } \\
\text { Archaeological Dates (Two } \\
\text { Sigma Calibrated Age Range (cal } \\
\text { BP) }{ }^{1}\end{array}$ & $\begin{array}{c}\text { Primary Archaeological } \\
\text { Culture Attributions }^{2}\end{array}$ \\
\hline I(la) & $3400-5000$ & $4240-3990$ & Denbigh \\
\hline II(Ila) & $2400-2800$ & $3380-3210$ & Late Denbigh, Choris \\
\hline III & $2100-3000$ & $3210-2960$ & Old Whaling, Choris \\
\hline IV & $2300-2700$ & $2780-2740$ & $\begin{array}{c}\text { Norton-Near Ipiutak, } \\
\text { Birnirk }\end{array}$ \\
\hline V & $1700-2000$ & $2310-2063$ & $\begin{array}{c}\text { Ipiutak, Thule (Late } \\
\text { Western Thule) }\end{array}$ \\
\hline VI(a,b) & 1300 to present & $1310-1180$ & $\begin{array}{c}\text { Thule (Early Western } \\
\text { Thule-Late }\end{array}$ \\
& & & $\begin{array}{c}\text { Thule/Kotzebue), Historic } \\
\text { Inupiat }\end{array}$ \\
\hline
\end{tabular}

${ }^{1}$ Calibrated with OxCal 4.3.2 (Bronk Ramsey 2017) IntCal13 (Reimer et al. 2013) and Marine13

(Reimer et al. 2013).

${ }^{2}$ There are younger occupations on each ridge. See Figure 7.

\subsection{Discussion}

\subsection{The CAKR Beach Ridge Complexes as a Proxy of Coastal Climate Change}

This study highlights the complexities of interpreting regional climatic trends from beach ridge formation and erosion processes. Previously, the deposition of individual beach ridges, sets of beach ridges, and the mechanisms and timing of their erosion (and differentiation as definable units), were interpreted to be related to long-term fluctuations in wind and wave climate, storm frequency and intensity, and sediment availability (e.g. Jordan and Mason 1999; Mason and Jordan 1993). Secular changes in sea level also contribute to changes in coastal sedimentation patterns, and while regional data indicate that sea level has been rising slowly over the past 3000 to 5000 years (Jordan and Mason 1999), the influence of meteorological events, shifts in climate regimes, and interruptions of sediment availability were considered to be more significant in the long-term evolution of the CAKR beach ridge complex during the mid-late Holocene than the slow rate of late Holocene sea level rise (cf. Moore, 1960; Hopkins, 1977; Mason and Ludwig, 1990; Jordan and Mason, 1999). However, we also find that relatively minor shifts in the coastal environment at CAKR can significantly alter coastal depositional processes. It is well documented elsewhere that significant geomorphological alterations of mixed-sandgravel beach ridge systems can be driven by several processes operating in the coastal system, not all of them driven by climate change (Carter, 1983; Orford, 1987; Anthony, 2009).

Our results suggests that further research on the correlations between Chukchi Sea beach ridge systems and past climate change is needed to further explore this new evidence from CAKR. Additional research on the subsurface stratigraphic record of beach ridge formation and erosion is required to more fully understand the dominant processes of ridge development at CAKR. While there are limitations to some of these approaches, e.g. geologic trenching, and the use of ground-penetrating 
radar (Urban et al., 2016), improved means of the examining geologic setting and evolution of this system is warranted.

\subsection{Post-depositional Modification of the Cape Krusenstern Beach Ridge Plain: Environmental and Archaeological Implications}

Climate and hydrological dynamics modified the form of beach ridges and ridge sets on the Cape long after the ridges were originally deposited. These processes have significance both for understanding more recent coastal environmental processes and for interpreting archaeological data, much of which was altered or erased by post-depositional erosion and other natural processes. Many lakes that occur on the northern half of the complex show evidence of fluctuating levels and several of the linear, semi-rectangular east-west oriented ridge sets at lake edges (see Figure 5, inset 3) exhibit distinct sets of three to five beach ridges inset into and rising from their east and west shores. Minimal soil development and vegetation cover on these lake-ridge sets suggests that they are comparatively young, possibly relating to increased wave action and lake margin erosion/deposition during the LIA. The growth and expansion of ice wedges and ice wedge polygons also has played a role in the dynamics of lake formation on the cape; wedges that cross-cut beach ridges often generate deep surface troughs that fill with water during summer thawing of the active layer. Numerous lakes that would otherwise be confined to the swales between ridges are now connected across ridges by this process, and in some cases these lakes have flooded and expanded across multiple low-elevation ridges, especially in the northwest sector of the beach ridge complex.

The largest and most conspicuous lakes have expanded across many ridges of Unit II, and record hydro-geomorphological processes observed in lake systems that have developed in similar sedimentological settings and scales in lower latitudes (Ashton, personal communication 2012). The shoreline configuration of lakes and spits prograding into them observed today is similar in detail to what they were in 1950, the date of the first available aerial photographs of CAKR (see Giddings and Anderson 1986:16). Thus, there has been little or no substantive change in the size or location of these spits during the past $60+$ years, suggesting that they must have formed during decades to a few hundred years at most, and prior to the mid- $20^{\text {th }}$ century. Considering the existence of relict but young lake-end beach ridge sets that must have been deposited during a regime of higher wave-energy and storminess than present (see above), and proxy data from around Kotzebue Sound that indicate increased storminess between AD 1400 and 1800 (Mason and Gerlach, 1995a; Graumlich and King, 1997; Mason and Barber, 2003), we suggest that the most recent and geomorphologically significant period of lake expansion and segmentation at CAKR occurred sometime between 450 and 150 years ago $\left(16^{\text {th }}\right.$ and $19^{\text {th }}$ centuries $A D$ ), concurrent with LIA cooling. The expansion of these lakes, due to wave action and/or thermokarst processes, has destroyed part of Unit la and almost half the surface of Unit II, and potentially many archaeological sites dating to this time period. Regional sea-level and mean annual temperature are slowly rising, so eventually we should expect additional inundation of beach ridges and swales that are open to the Tukrok wetlands, a gradually lowering permafrost table, and the potential destruction of the terminal ends of beach ridges and associated sites.

\subsection{Integrating Geological and Archaeological Models of Coastal Change}

New geological and archaeological data reinforce our previous conclusion (Anderson and Freeburg, 2013) that ridges are not good stratigraphic markers beyond providing maximum limiting ages. New data also clarify the Unit V/VI boundary (previously Units I and II); the Late Western Thule site is now in Unit V and Early Western Thule is now in Unit VI. These shifts in the stratigraphic 
placement of key sites are significant only in that the changes further illustrate that beach segments are not precise time markers. The new dates and data do not significantly alter our understanding of local settlement patterns (detailed in Anderson and Freeburg, 2014) but do provide additional context for understanding changing settlement patterns and also patterns in local site preservation. Furthermore, maximum limiting archaeological ages older than geologic ages occurred in several instances (i.e. Unit II/Ila, Unit III, and Unit V); in these cases, the ridges could be older than the geologic age indicates. Or, the archaeological ages could be the result of old wood. Additional geologic sampling and dating would resolve these discrepancies.

Our geomorphological analysis further supports the hypothesis that initial formation and occupation of the CAKR complex took place during a period of relatively stable coastal processes between about 5000 and 3000 years ago. This evidence indicates a relationship between local and regional development of beach ridge systems that were amenable to human occupation of the coast and the initial development of maritime adaptations in northwest Alaska; perhaps people focused more on marine mammal hunting and fishing when it became easier to access these resources than during previous decades or centuries. Alternatively, the coastal marine environment was particularly productive during this time period. Both hypotheses could be further explored with additional paleoenvironmental research. Occupation of CAKR was limited during this time period. This could be due to a) low regional population during this period, or b) poor site preservation in these areas due to post-depositional processes of lake and ice wedge development.

Between about 2100 and 1000 years ago, the coastal landscape changed significantly at CAKR, which could be a result of increased regional storminess and/or a fluctuation in sediment supply to the system. Despite this shift in environmental conditions, local settlement increased during this period (Anderson and Freeburg, 2014); we interpret the local settlement pattern as one of increased residential sedentism and increased density of occupation over time. Locally, there is a shift in landscape development processes around $1000 \mathrm{cal} \mathrm{BP}$; this shift coincides with local and regional population decline followed by rapid increase in local and regional population between 1000 and 550 cal BP (Anderson et al. in review). Erosion at Cape Krusenstern around this time is likely masking or impacting the evidence of past demographics around $1000 \mathrm{cal} \mathrm{BP}$, and enhancing the decline or dip in the regional occurrence or visibility of sites at this time. However, Anderson et al.'s (in review) analysis of occupation patterns of individual sites across the coasts and interiors of the region shows that some sites were occupied during this period of decline; the patterns in the radiocarbon data cannot be attributed solely to coastal erosion at this time. Further exploration of regional climate change around $1000 \mathrm{cal}$ BP will further inform our understanding of this critical period of cultural change, when the earliest named archaeological culture (Birnirk) known to be ancestral to Iñupiat and Inuit people first populated the region.

After $1000 \mathrm{cal}$ BP depositional patterns shift, with deposition happening primarily on the west and southwest areas of the beach ridge complex and erosion occurring to the east. After $550 \mathrm{cal} B \mathrm{PP}$ there appears to be a decrease in local population that mirrors a regional population decline or redistribution, although the post-550 cal BP decline in radiocarbon dates may also be a product of sampling or calibration effects (see Anderson and Freeburg 2014; Anderson et al. in review for further discussion). The formation of LIA cooling-related lake development and ice wedge formation at CAKR indicates that the LIA had a significant local environmental impact; these changes could have altered subsistence resource availability and led to settlement redistribution as others have suggested for this time period (Giddings and Anderson 1986; Harritt 1994). These processes also reduced archaeological 
site preservation, particularly in Unit II of the CAKR complex, and should be considered when interpreting local settlement patterns, demography, and settlement density.

\subsection{Conclusions and Future Work}

Our goals were 1) to refine local cultural and paleoenvironmental chronologies through a synthesis of new geomorphological and archaeological data, and 2) to explore how local coastal environmental change may have influenced local and regional settlement history. New geomorphological data show that beach ridges are composites and the boundaries defined between units are not necessarily precise time-stratigraphic indicators from a geomorphological or an archaeological perspective. The revised chronology and depositional units confirm and refine initial interpretation of the local archaeological chronology. It is also apparent where more dates and data are needed to further explore some of the questions raised here (e.g. additional sampling in Unit II). Furthermore, reconstruction of the local coastal paleoenvironment provides critical information about patterns of archaeological site preservation and informs interpretation of coastal forager settlement and demographic patterns. Our results also suggest that relatively minor or short-term shifts in the coastalmarine environment at CAKR can significantly alter coastal depositional and erosional processes. A minor reorientation of a set of beach ridges records a perturbation in coastal depositional dynamics but it does not necessarily reflect pervasive regional- scale climate change, such as shifts in storminess (sensu Mason and Jordan 1993). Our work suggests that there may have been multiple drivers in the development of regional beach ridge systems, including but not limited to major periods of storminess. This possibility should be further explored through continued research on the relationship between beach ridge geomorphology and regional climate change. Continued efforts to build paleoenvironmental reconstructions of higher temporal and spatial resolution for the region will help address remaining questions about the relationship between local coastal environmental changes and regional patterns, and the impacts of these environmental shifts on local residents.

\section{Funding Sources}

This research was funded by the National Park Service through a cooperative agreement (J8W07070032) managed the Pacific Northwest Cooperative Ecosystem Study Unit and with support from the Great Lakes-Northern Forest Cooperative Ecosystem Studies Unit (GLNF CESU, Task Agreement \# J979108J048).

\section{Acknowledgements}

Many thanks to the Kotzebue and northwest Alaska communities for the opportunity to carry out this research. Douglas D. Anderson, Eileen Devinney, Robert Gal, and Ben trema made important contributions to this research. Thomas Brown assisted with Figure 7 preparation. Western Arctic National Park Service staff provided logistical and outreach support. Editorial and reviewer comments much improved our original manuscript. All errors and omissions are the responsibility of the authors.

\section{Declarations of interest}

None

\section{Data Availability}

Radiocarbon data used in this analysis are supplied as tables and supplementary tables. Other radiocarbon data are published (Anderson and Freeburg 2013). Spatial data and other information are available at the National Park Service Alaska Regional Curation Center. 


\section{References Cited}

Alix, C., O. Mason, S. Anderson, R. Bogardus, N. Bigelow, A. Lincoln, L. Norman, C. Maio, M. Vanlandeghem, D. O'Rourke, J. Rasic, M. Lorain, A. Prentiss, 2018. Birnirk Prehistory and the Emergence of Inupiaq Culture in Northwestern Alaska: Archaeological and Anthropological Perspectives. Field Investigations at the Cape Espenberg, 2017. Annual Report to the National Park Service.

Anderson, D.D., 1962. Cape Krusenstern Ipiutak economic and settlement patterns. Unpublished MA Thesis, Brown University.

Anderson, D.D., 1984. Prehistory of North Alaska. In: Damas, D. (Ed.), Arctic: Handbook of North American Indians. Smithsonian Institution Press, Washington D.C., pp. 80-93.

Anderson, S.L., Freeburg, A.K., 2013. A high-resolution chronology for the Cape Krusenstern site complex, Northwest Alaska. Arctic Anthropology, 50 (1).

Anderson, S.L., Freeburg, A.K., 2014. High latitude coastal settlement patterns: Cape Krusenstern, Alaska. The Journal of Island and Coastal Archaeology, 9 (3), 295-318.

Anderson, S.L., Brown, T.J., Junge, J., Duelks, J., in review. Demographic fluctuations and the emergence of Arctic maritime adaptations.

Anthony, E.J., 2009. Shore processes and their paleoenvironmental applications. Elsevier, New York. Bockstoce, J.R., 1973. A prehistoric population change in the Bering Strait region. Polar Record, 16, 792803.

Bronk Ramsey, C., 2017. Methods for summarizing radiocarbon datasets. Radiocarbon, 59(2), 18091833.

Carter, R.W.G., 1983. Raised coastal landforms as products of modern process variations, and their relevance in eustatic sea-level studies: examples from eastern Ireland. Boreas, 12, 167-182.

Clark, P.U., A.S. Dyke, J.D. Shakun, A.E. Carlson, J. Clark, B. Wohlfarth, J.X.Mitrovica, S.W. Hostetler, A.M. McCabe., 2009. The Last Glacial Maximum, 325(5941), 710-714.

Darwent, J. and C. Darwent, 2005. Occupational history of the Old Whaling Site at Cape Krusenstern, Alaska. Alaska Journal of Anthropology, 3(2):135-154.

Dixon, J.C., 2003. Environment and Environmental Change in the Western Arctic and Subarctic: Implications for Whaling. In: McCartney, A.P. (Ed.), Indigenous Ways to the Present: Native Whaling in the Western Arctic. Canadian Circumpolar Institute (CCI) Press and The University of Utah Press, Edmonton and Salt Lake City, pp. 1-24.

Fathauer, T., 1975. The great Bering Sea storms of 9-12 November 1974. Weatherwise 28, 76-83.

Freeburg, A.K. and S.L. Anderson, 2012. 200 Generations on the Beach of Their Time: HumanEnvironmental Dynamics at Cape Krusenstern. Final project report prepared for the National Park Service.

Friesen, T.M., Arnold, C.D., 2008. The timing of the Thule migration: new dates from the western Canadian Arctic. American Antiquity, 73, 527-538.

Gerlach, C. and O.K. Mason, 1992. Calibrated radiocarbon dates and cultural interaction in the Western Arctic. Arctic Anthropology, 29(1):54-81.

Giddings, J.L., 1966. Cross-dating the archeology of northwestern alaska. Science, 153, 127-35.

Giddings, J.L., 1967. Ancient Men of the Arctic. Knopf, New York.

Giddings, J.L., Anderson, D.D., 1986. Beach Ridge Archeology of Cape Krusenstern: Eskimo and PreEskimo Settlements Around Kotzebue Sound, Alaska. National Park Service, Washington, D.C.

Goodwin, I.A., 2005. Unravelling climatic influences on Late Holocene sea level variability. In: Mackay, A., Battarbee, R., Birks, J., Oldfield, F. (Eds.), Global Change in the Holocene. Hodder Arnold, New York, pp. 406-521.

Graf, K., 2009. "The good, the bad, and the ugly": evaluating the radiocarbon chronology of the middle 
and late Upper Paleolithic in the Enisei River valley, south-central Siberia. Journal of Archaeological Science, 36, 694-707.

Graumlich, L., King, J.C., 1997. Late Holocene climatic variation in Northwestern Alaska as reconstructed from tree rings. Report to the National Park Service, Anchorage.

Hall, E.S.J., 1978. Technological change in North Alaska. In: Dunnell, R., Hall Jr., E.S. (Eds.), Archaeological Essays in Honor of Irving B. Rouse. Mouton, New York, pp. 209-229.

Harritt, R.K., 1994. Eskimo prehistory on the Seward Peninsula. National Park Service, Anchorage.

Hoffecker, J.F., Elias, S.A., 2003. Environment and archaeology in Beringia. Evolutionary Anthropology, 12, 34-49.

Hopkins, D.M., 1977. Coastal processes and coastal erosional hazards to the Cape Krusenstern archaeological site. U.S. Geological Survey Open-File Report 77-32.

Hume, J.D., Shalk, M., 1967. Shoreline processes near Barrow, Alaska: a comparison of the normal and the catastrophic. Arctic, 20, 86-103.

Jordan, J.W., 2009. Arctic Climate and Landscape ca. AD 800-1400. In: Maschner, H., Mason, O.K., McGhee, R. (Eds.), The Northern World AD 900-1400. University of Utah Press, Salt Lake City, pp. 7-29.

Jordan, J.W., Mason, O.K., 1999. A 5000-year record of intertidal peat stratigraphy and sea level change from northwest Alaska. Quaternary International, 60, 37-47.

Kaufman, D.S., Axford, Y.L., Henderson, A.C.G., McKay, N.P., Oswald, W.W., Saenger, C., Anderson, R.S., Bailey, H.L., Clegg, B., Gajewski, K., Hu, F.S., Jones, M.C., Massa, C., Routson, C.C., Werner, A., Wooller, M.J., Yu, Z., 2016. Holocene climate changes in eastern Beringia (NW North America) - A systematic review of multi-proxy evidence. Quaternary Science Reviews, 147, 312-339.

Kuzmin, Y. V., Keates, S.G., 2018. Siberia and neighboring regions in the Last Glacial Maximum: did people occupy northern Eurasia at that time? Archaeological and Anthropological Sciences, 10,

Mason, O.K., 1998. The contest between the Ipiutak, Old Bering Sea, and Birnirk polities and the origin of whaling during the first millennium A.D. along Bering Strait. Journal of Anthropological Archaeology, 17, 240-325.

Mason, O.K., 2009a. Flight from the Bering Strait: Did Siberian Punuk/Thule military cadres conquer northwest Alaska? In: Maschner, H., Mason, O.K., McGhee, R. (Eds.), The Northern World Ad 9001400. University of Utah Press, Salt Lake City, pp. 76-128.

Mason, O.K., 2009b. "The Multiplication of Forms:" Bering Strait Harpoon Heads as a Demic and Macroevolutionary Proxy. In: Prentiss, A.M. (Ed.), Macroevolution in Human Prehistory. Springer, New York, pp. 73-107.

Mason, O.K., Barber, V., 2003. A paleo-geographic preface to the origins of whaling: cold is better. In: McCartney, A.P. (Ed.), Indigenous Ways to the Present: Native Whaling in the Western Arctic. Canadian Circumpolar Institute (CCI) Press and the University of Utah Press, Edmonton and Salt Lake City, pp. 69-108.

Mason, O.K., Gerlach, S.C., 1995a. Chukchi Sea hot spots, paleo-polynyas and caribou crashes: climatic and ecological constraints on northern Alaska prehistory. Arctic Anthropology, 32, 101-130.

Mason, O.K., Gerlach, S.C., 1995b. The archaeological imagination, zooarchaeological data, the origins of whaling in the western Arctic, and "Old Whaling" and Choris cultures. In: McCartney, A.P. (Ed.), Hunting the Largest Animals. The Canadian Circumpolar Institute, Calgary, pp. 1-31.

Mason, O.K., Jordan, J.W., 1993. Heightened North Pacific storminess and synchronous late Holocene erosion of northwest Alaska beach ridge complexes. Quaternary Research, 40, 55-69.

Mason, O.K., Jordan, J.W., 1997. Late Holocene sea level and storm history of the northern Seward Peninsula: the coastal preocesses of the Shared Beringian Heritage Project. Final Report to the National Park Service, Anchorage.

Mason, O.K., Jordan, J.W., 2002. Minimal late Holocene sea level change in the Chukchi Sea: Arctic 
insensitivity to global change? Global and Planetary Change, 32, 13-23.

Mason, O.K., Ludwig, S.L., 1990. Resurrecting beach ridge archaeology: parallel depositional records from St.Lawrence Island and Cape Krusenstern. Geoarchaeology, 5, 349-373.

Mason, O.K., Jordan, J.W., Plug, L., 1995. Late Holocene storm and sea-level history in the Chukchi Sea. Journal of Coastal Research Special Issue No.17: Holocene Cycles: Climate, Sea Levels, and Sedimentation 17, 173-180.

Mason, O.K., Hopkins, D.M., Plug, L., 1997. Chronology and paleoclimate of storm-induced erosion and episodic dune growth across Cape Espenberg Spit, Alaska, U.S.A. Journal of Coastal Research, 13, 770-797.

McClenahan, P.L., 1993. An Overview and Assessment of Archeological Resources, Cape Krusenstern National Monument, Alaska. National Park Service, Anchorage.

McClenahan, P.L., Gibson, D.E., 1990. Cape Krusenstern National Monument: an Archeological Survey. National Park Service, Anchorage.

McGhee, R., 2000. Radiocarbon dating and the timing of the Thule migration. In: Appelt, M., Berglund, J., Gullov, H.C. (Eds.), Identities and Cultural Contacts in the Arctic. Danish National Museum and Danish Polar Centre, Copenhagen, pp. 81-191.

McGhee, R., 2009. When and why did the Inuit move to the Eastern Arctic? In: Maschner, H., Mason, O.K., McGhee, R. (Eds.), The Northern World AD 900-1400. University of Utah Press, Salt Lake City, pp. 155-163.

Minc, L.D., Smith, K.P., 1989. The spirit of survival: cultural responses to resource variability in North Alaska. In: Halstead, P., O'Shea, J. (Eds.), Bad Year Economics: Cultural Responses to Uncertainty and Risk. Cambridge University Press, Cambridge, pp. 8-39.

Moore, G.W., 1960, Recent eustatic sea-level fluctuations recorded by Arctic beach ridges. In U.S. Geological Survey, Geological survey research 1960, Short papers in the geological sciences: U.S. Geological Survey Professional Paper 400-B, p. B335-B337.

Moore, G.W., 1966. Arctic beach sedimentation. In: NWilimovsky, N., Wolfe, J.N. (Eds.), Environment of the Cape Thompson Region, Alaska. Atomic Energy Commission, Oak Ridge, pp. 587-608.

Moore, G.W., Giddings, J.L., 1961. Record of 5000 years of Arctic Wind Direction Recorded by Alaskan Beach Ridges. Geological Society of America Special Paper No. 68, 232.

Morrison, D., 2009. The "Arctic maritime" expansion: a view from the western Canadian Arctic. In: Maschner, H., Mason, O.K., McGhee, R. (Eds.), The Northern World AD 900-1400. University of Utah Press, Salt Lake City, pp. 164-178.

Murray, M., Robertson, A.C., Ferrara, R., 2003. Chronology, culture, and climate: a radiometric reevaluation of late prehistoric occupations at Cape Denbigh, Alaska. Arctic Anthropology, 40, 87105.

Orford, J.D., 1987. Coastal processes: the coastal response to sea-level variation. In: Devoy, R.J.N. (Ed.), Sea Surface Studies: A Global View. Croom Helm, New York, pp. 415-463.

Orford, J.D., R.W.G. Carter, J. McKenna, and S.C. Jennings. 1995. The relationship between the rate of mesoscale sea-level rise and the rate of retreat of swash-aligned gravel-dominated barriers. Marine Geology, 124: 177-186.

Ramsey, C.B., 2009. Bayesian analysis of radiocarbon dates. Radiocarbon, 51, 337-360.

Reimer, P.J., Bard, E., Bayliss, A., Beck, J.W., Blackwell, P.G., Ramsey, C.B., Buck, C.E., Cheng, H., Edwards, R.L., Friedrich, M., 2013. IntCal13 and Marine13 Radiocarbon Age Calibration Curves 0-50,000 years cal BP. Radiocarbon, 55, 1869-1887.

Rinck, B. and O.K. Mason, 2015. Geoarchaeological Assessment of Landforms Adjacent to the Intermediate Kotzebue Site (KTA-030), Kotzebue, Northwest Arctic Borough, Alaska. Report to Brice, Inc., SWCA, Seattle.

Rowley-Conwy, P., 1999. Introduction: human occupation of the Arctic. World Archaeology: Arctic 
Archaeology, 30, 349-353.

Schaaf, J.M., 1988. The Bering Land Bridge National Preserve: an Archaeological Survey. National Park Service, Anchorage.

Taylor, W.E., 1963. Hypotheses on the origin of Canadian Thule culture. American Antiquity, 28, 456464.

Tremayne, A.H., Winterhalder, B., 2017. Large mammal biomass predicts the changing distribution of hunter-gatherer settlements in mid-late Holocene Alaska. Journal of Anthropological Archaeology, 45, 81-97.

Urban, T.M., Rasic, J.T., Alix, C., Anderson, D.D., Manning, S., Mason, O.K., Tremayne, A.H., Wolff, C.B., 2016. Frozen: the potential and pitfalls of ground-penetrating radar for archaeology in the Alaskan Arctic. Remote Sensing, 8, 1007.

Zimmerman, G., 1981. Site detection through the utilization of aerial photographs, Cape Krusenstern. University of Alaska-Fairbanks, Fairbanks. 


\section{Figures}

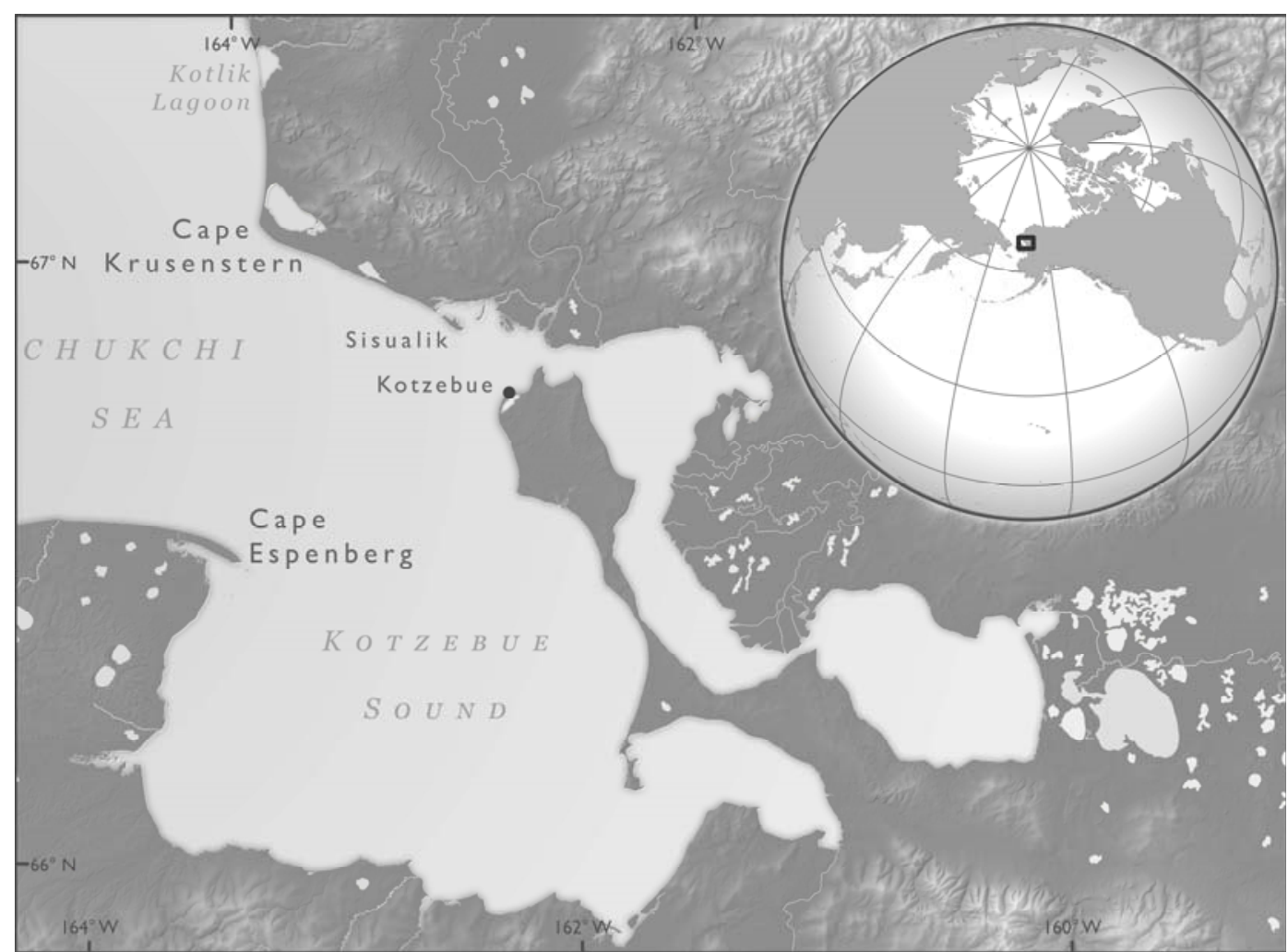

Figure 1. Map indicating location of project area in northwest Alaska. Locations discussed in text indicated (Figure by Adam K. Freeburg). 


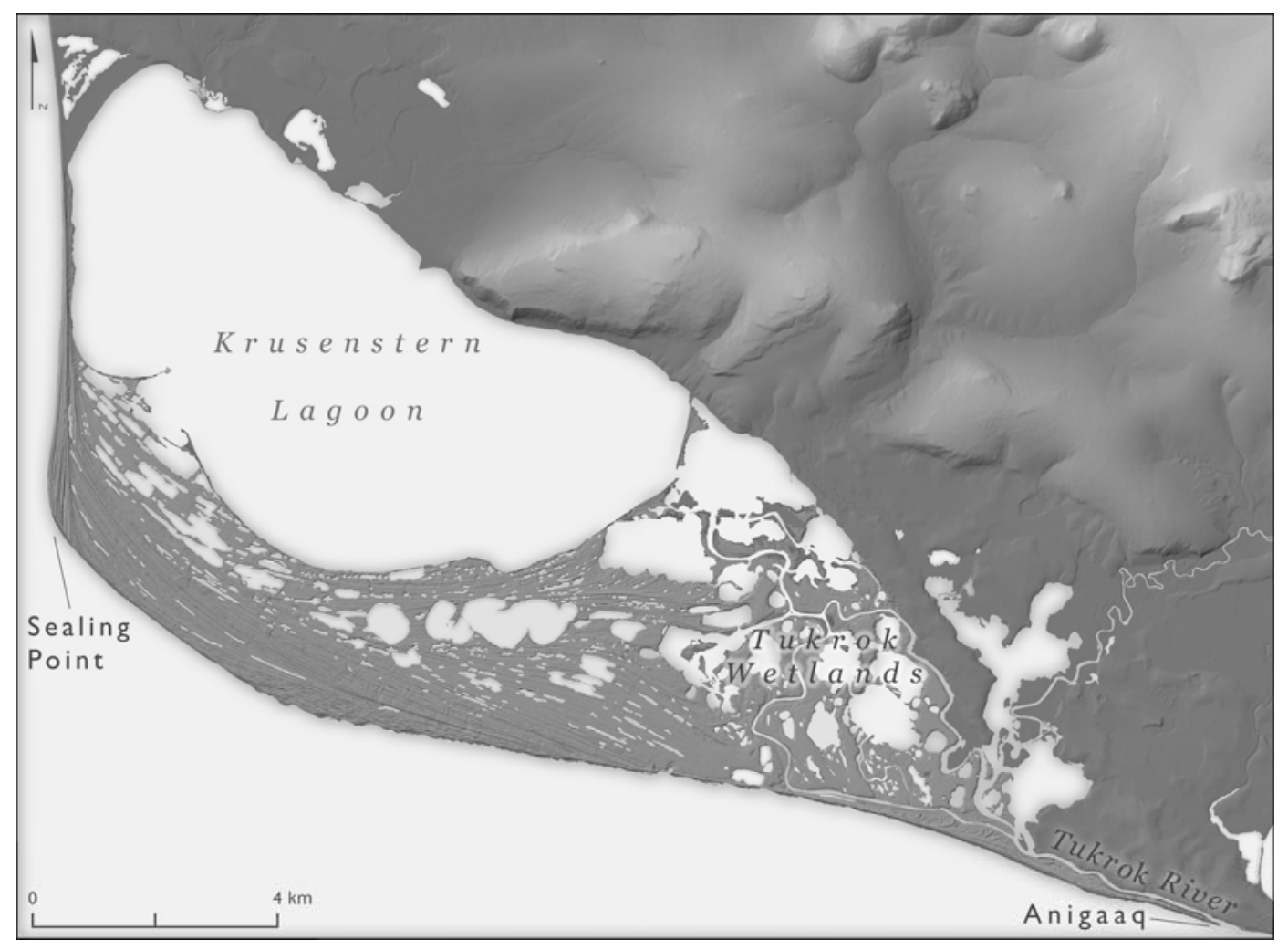

Figure 2. Cape Krusenstern beach ridge system with local landmarks indicated (Figure by Adam K. Freeburg). 


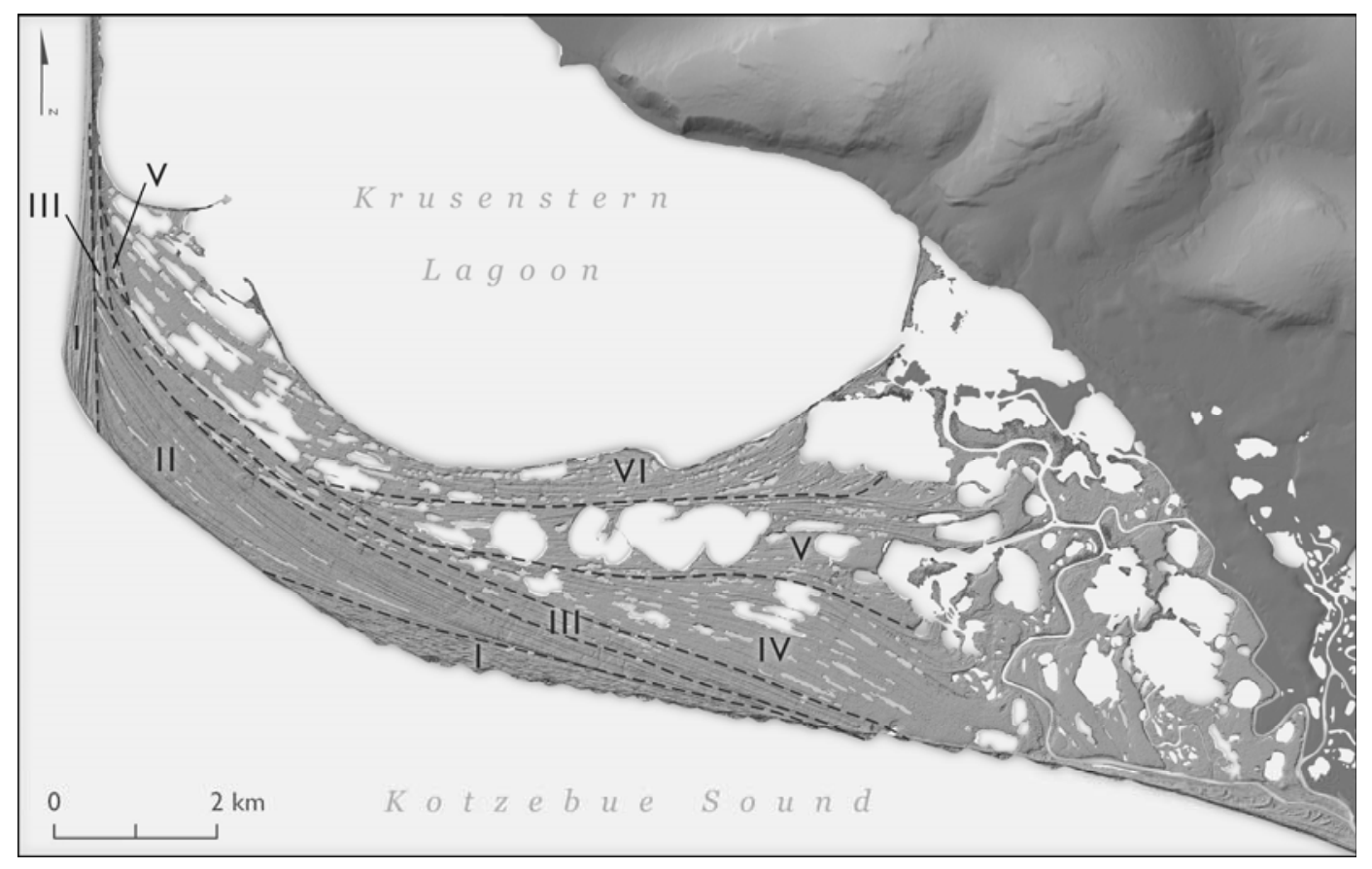

Figure 3. Previously established beach ridge depositional units indicated by roman numerals, with notation following Giddings and Anderson (1986) (see also Mason and Ludwig 1990; Mason and Jordan 1993; Moore 1960, 1966) (Figure by Adam K. Freeburg).

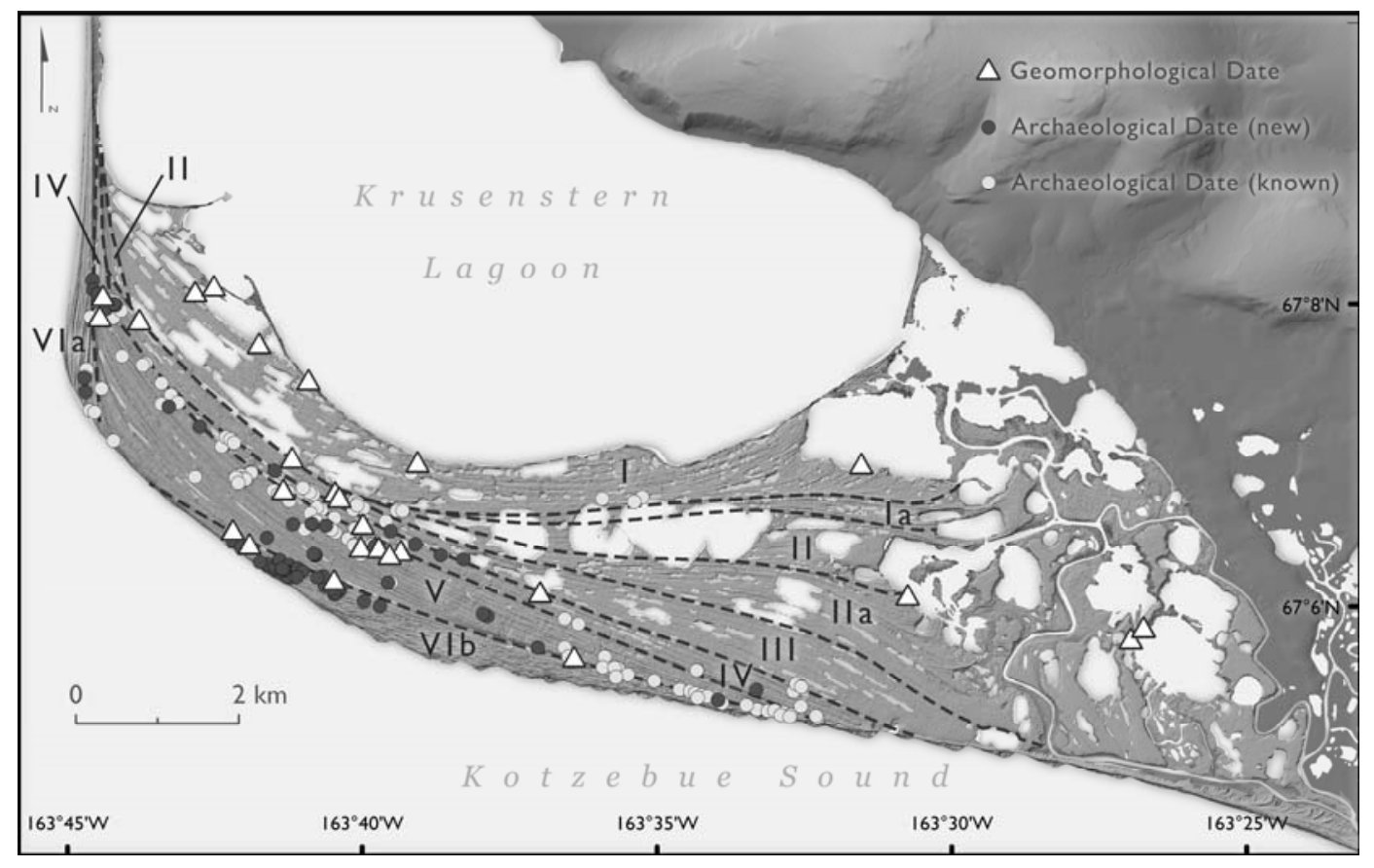

Figure 4. Geological depositional units (see Section 4.1 for discussion) and newly dated locations are indicated by circles (cultural samples) and triangles (geomorphological samples) (Figure by Adam K. Freeburg). 


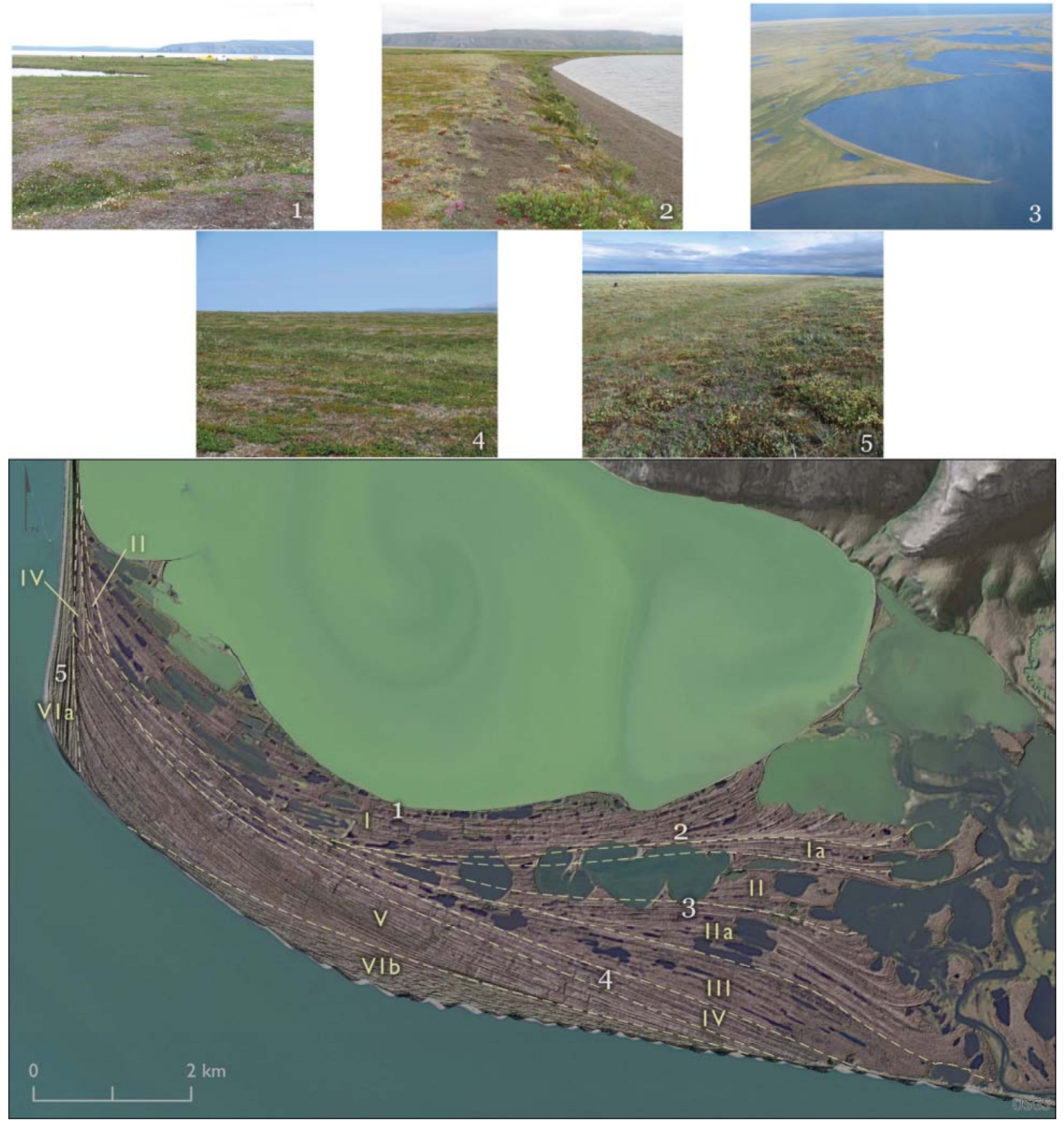

Figure 5. (Top) Photos of several areas of the beach ridge complex, illustrating differences in geomorphology across the beach segments. 1) Unit I, note ice wedge development across ridges, view $\mathrm{N}$; 2) Unit IA, younger, higher rides of unit being eroded by expansion of large lake system across northeast sector of complex, view E; 3) Unit II, Ila, low-elevation, semi-discontinuous ridges begin eroded by expansion of same lake system impacting Unit I ridges, view W; 4) Unit IV/V, closely spaced, well drained, high elevation ridges near middle of complex, view NW; 5) Unit VI, relatively young, sparsely vegetated ridges along western margin of complex, view N. (Bottom) Arabic numerals indicate photo inset locations (Figure by Adam K. Freeburg). 


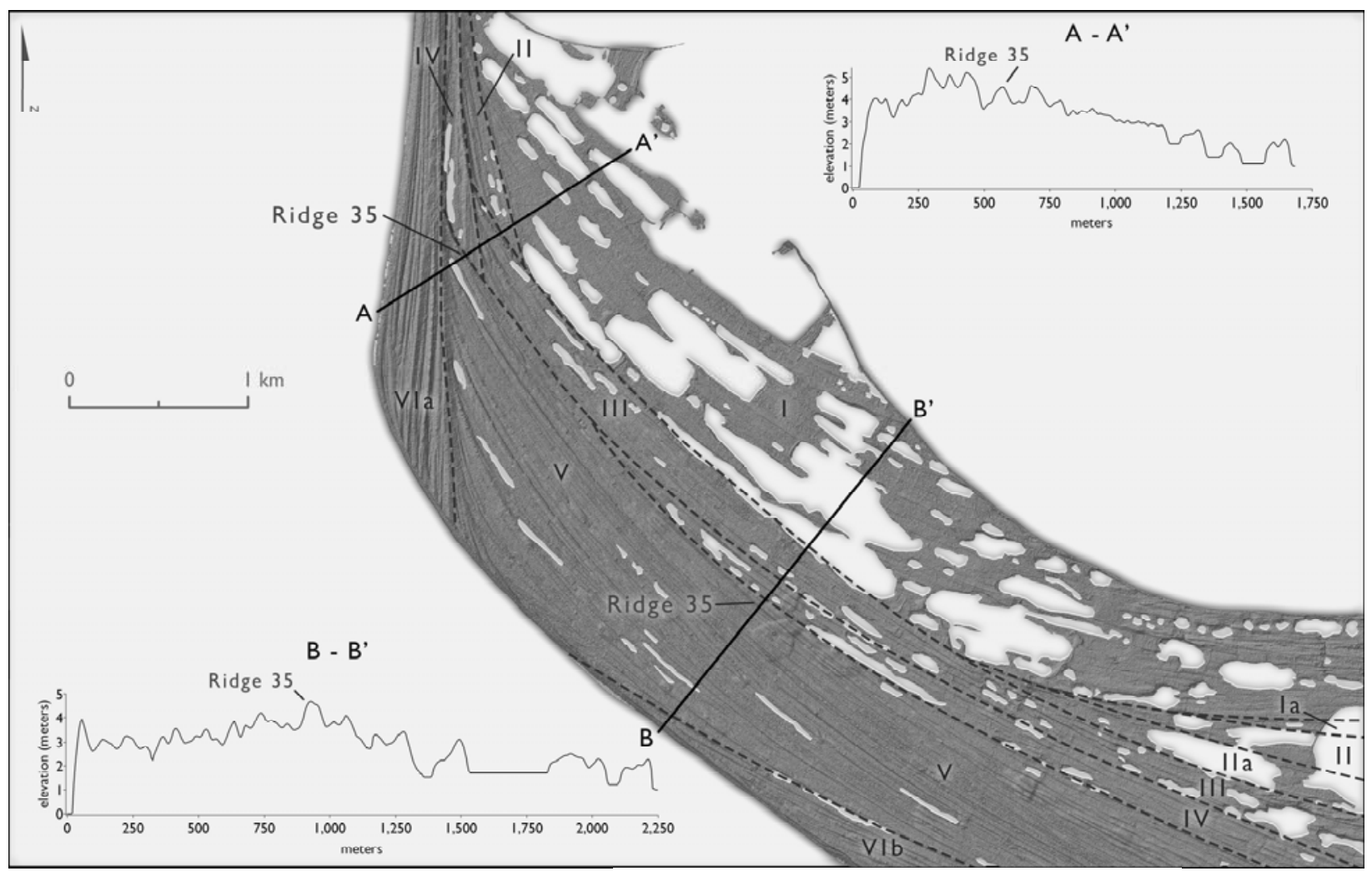

Figure 6. Topographic profile of two transects. Topographic profiles are derived from USGS interferometric synthetic aperture radar (IfSAR) digital terrain model data. Note the overall change in elevation over time and the shape of the ridges at different points in time. Ridge 35 was identified by Giddings (1984) as the "main Ipiutak ridge". Because it is a fairly continuous ridge, we indicate the location of Ridge 35 on both profiles to show how a ridge's and relative height changes throughout the complex (Figure by Adam K. Freeburg). 

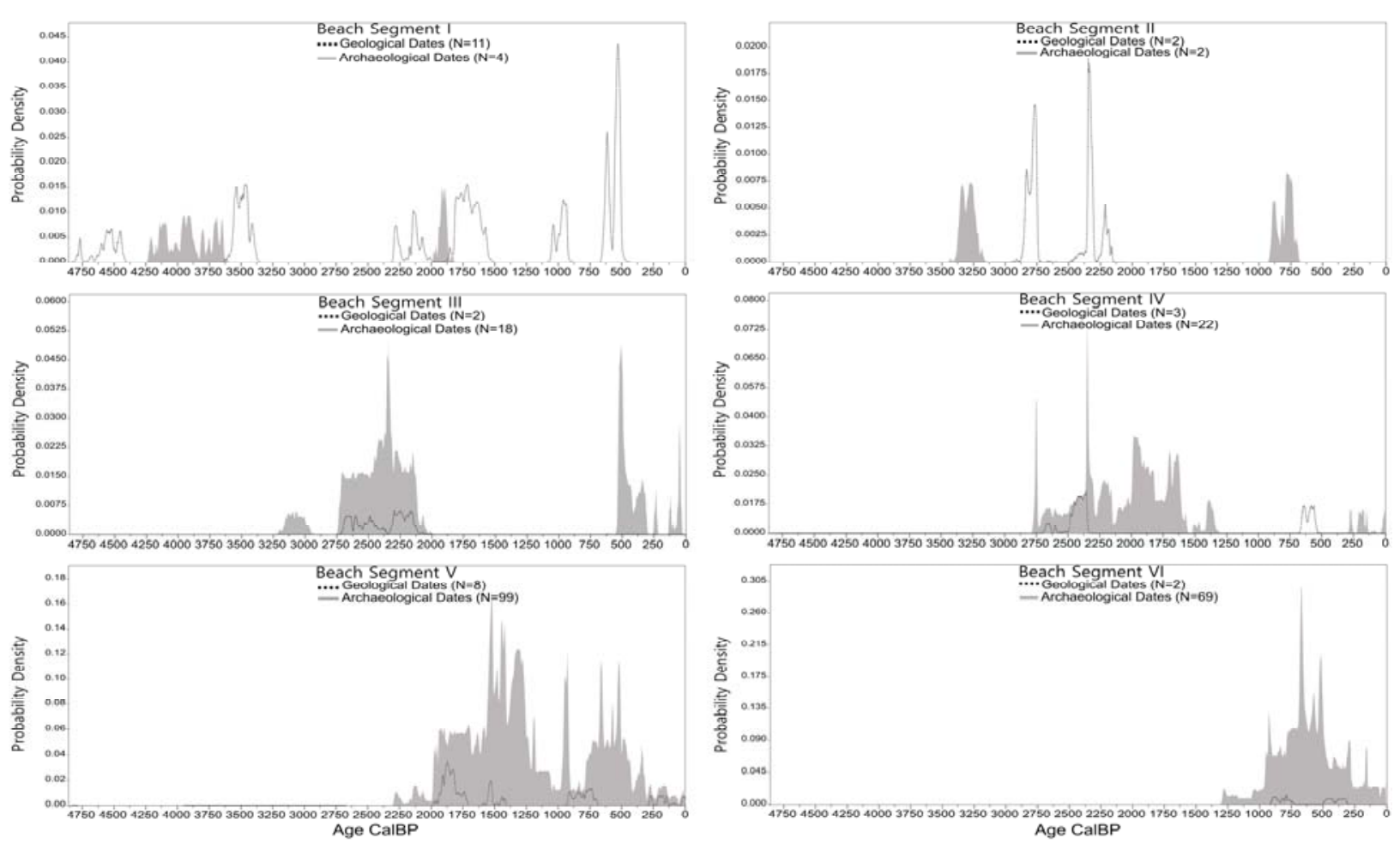

Figure 7. Summed probability distribution (SPD) plots of all archaeological and geological radiocarbon dates from Cape Krusenstern. The dates are plotted by beach ridge segment. Note the relationship between the geologic and archaeological dates, and also the extended occupation of even the oldest beach segments (e.g. Unit I) (Figure by Thomas J. Brown). 


\begin{tabular}{|c|c|c|c|c|c|c|c|c|c|}
\hline Acrecciont & COMPC & & Beach & & 513 cis & onvention & A En Eror & Iongitudo & Iatitude \\
\hline OS-93762 & Surface & & 3 & Picea & -26.95 & 2440 & 30 & $163^{\circ} 38.1582^{\prime} \mathrm{W}$ & $67^{\circ} 6.44616^{\prime} \mathrm{N}$ \\
\hline OS-93939 & $2 \mathrm{~cm} \mathrm{BS}$ & & 3 & $\begin{array}{c}\text { Unidentified } \\
\text { hardwood }\end{array}$ & -26.42 & 55 & 25 & $163^{\circ} 43.98606^{\prime} \mathrm{W}$ & $67^{\circ} 8.17152^{\prime} \mathrm{N}$ \\
\hline OS-93951 & $10 \mathrm{cmBS}$ & Level 1 & 3 & Picea & -24.51 & 2200 & 30 & $163^{\circ} 44.0025^{\prime} \mathrm{W}$ & $67^{\circ} 8.18208^{\prime} \mathrm{N}$ \\
\hline OS-93945 & $14 \mathrm{cmBD}$ & Level 1 & 4 & Salicaceae & -26.02 & 2030 & 25 & $163^{\circ} 38.54214^{\prime} W$ & $67^{\circ} 6.47808^{\prime} \mathrm{N}$ \\
\hline OS-93946 & $9 \mathrm{cmBD}$ & Level 1 & 4 & Picea & -25.97 & 2220 & 25 & $163^{\circ} 39.38382^{\prime} W$ & $67^{\circ} 6.64356^{\prime} \mathrm{N}$ \\
\hline OS-94374 & "deep" & & 4 & Betula & -25.00 & 5410 & 100 & $163^{\circ} 38.97042^{\prime} W$ & $67^{\circ} 6.55296^{\prime} \mathrm{N}$ \\
\hline OS-93949 & $8 \mathrm{cmBD}$ & Level 1 & 4 & Betula & -26.34 & 2270 & 30 & $163^{\circ} 33.23724^{\prime} \mathrm{W}$ & $67^{\circ} 5.54004^{\prime} \mathrm{N}$ \\
\hline OS-94050 & $45 \mathrm{cmBD}$ & Level 4 & 4 & Picea & -25.45 & 2010 & 25 & $163^{\circ} 41.33202^{\prime} \mathrm{W}$ & $67^{\circ} 7.05876^{\prime} \mathrm{N}$ \\
\hline $\begin{array}{c}\text { Beta- } \\
326108\end{array}$ & $10 \mathrm{CM} B S$ & & 5 & Phoca, left femur & -13.2 & 1920 & 30 & $163^{\circ} 43.1085^{\prime} \mathrm{W}$ & $67^{\circ} 7.49406^{\prime} \mathrm{N}$ \\
\hline $\begin{array}{c}\text { Beta- } \\
326105\end{array}$ & $15 \mathrm{CM} B S$ & & 5 & $\begin{array}{l}\text { E. barbatus, left } \\
\text { innominate }\end{array}$ & -12.7 & 2230 & 30 & $163^{\circ} 44.1411^{\prime} \mathrm{W}$ & $67^{\circ} 8.14746^{\prime} \mathrm{N}$ \\
\hline OS-93943 & $33 \mathrm{~cm} \mathrm{BD}$ & Level 3 & 5 & Picea & -25.79 & 1900 & 30 & $163^{\circ} 40.47972^{\prime} \mathrm{W}$ & $67^{\circ} 6.68994^{\prime} \mathrm{N}$ \\
\hline OS-93942 & $74 \mathrm{cmBD}$ & Level 8 & 5 & cf. Conifer & -23.16 & 1440 & 30 & $163^{\circ} 40.72272^{\prime} W$ & $67^{\circ} 6.70302^{\prime} \mathrm{N}$ \\
\hline OS-93944 & $20 \mathrm{cmBD}$ & $\begin{array}{l}\text { Level } \\
3 \mathrm{~N}\end{array}$ & 5 & Salix & -27.69 & 1970 & 25 & $163^{\circ} 39.6582^{\prime} \mathrm{W}$ & $67^{\circ} 6.5478^{\prime} \mathrm{N}$ \\
\hline OS-93938 & $40-50 \mathrm{cmBD}$ & Level 5 & 5 & Picea & -27.03 & 1320 & 40 & $163^{\circ} 41.04126^{\prime} \mathrm{W}$ & $67^{\circ} 6.7023^{\prime} \mathrm{N}$ \\
\hline OS-93933 & $10-15 \mathrm{cmBD}$ & Level 1 & 5 & Salicaceae & -25.53 & 610 & 25 & $163^{\circ} 39.44628^{\prime} \mathrm{W}$ & $67^{\circ} 6.29904^{\prime} \mathrm{N}$ \\
\hline OS-94051 & $10 \mathrm{cmBS}$ & & 5 & Picea & -24.65 & 1480 & 30 & $163^{\circ} 37.7715^{\prime} \mathrm{W}$ & $67^{\circ} 6.06504^{\prime} \mathrm{N}$ \\
\hline OS-93950 & $7 \mathrm{cmBS}$ & & 5 & Picea & -24.89 & 1190 & 25 & $163^{\circ} 37.8483^{\prime} \mathrm{W}$ & $67^{\circ} 6.07938^{\prime} \mathrm{N}$ \\
\hline OS-93710 & $\sim 57 \mathrm{cmBS}$ & & 5 & Picea & -25.85 & 170 & 25 & $163^{\circ} 40.66878^{\prime} \mathrm{W}$ & $67^{\circ} 6.4971^{\prime} \mathrm{N}$ \\
\hline $\begin{array}{c}\text { Beta- } \\
326119\end{array}$ & $16-42 \mathrm{cmBS}$ & & 5 & $\begin{array}{l}\text { Phoca, right Tib/Fib } \\
\text { proximal epiphysis }\end{array}$ & -14.8 & 810 & 30 & $163^{\circ} 40.67178^{\prime} \mathrm{W}$ & $67^{\circ} 6.49542^{\prime} \mathrm{N}$ \\
\hline $\begin{array}{c}\text { Beta- } \\
326114\end{array}$ & $16-42 \mathrm{cmBS}$ & & 5 & $\begin{array}{c}\text { R. tarandus, left } \\
\text { astragalus }\end{array}$ & -17.8 & 210 & 30 & $163^{\circ} 40.67178^{\prime} \mathrm{W}$ & $67^{\circ} 6.49542^{\prime} \mathrm{N}$ \\
\hline OS-93687 & $10 \mathrm{cmBS}$ & & 5 & Picea & -26.93 & 115 & 25 & $163^{\circ} 40.67178^{\prime} \mathrm{W}$ & $67^{\circ} 6.49542^{\prime} \mathrm{N}$ \\
\hline OS-93686 & $49 \mathrm{cmBS}$ & & 5 & Picea & -23.17 & 485 & 25 & $163^{\circ} 40.67322^{\prime} \mathrm{W}$ & $67^{\circ} 6.49746^{\prime} \mathrm{N}$ \\
\hline OS-93688 & $12 \mathrm{cmBS}$ & & 5 & Picea & -24.11 & 410 & 25 & $163^{\circ} 40.7025^{\prime} \mathrm{W}$ & $67^{\circ} 6.50454^{\prime} \mathrm{N}$ \\
\hline
\end{tabular}

(c) 2018. This manuscript version is made available under the CC-BY-NC-ND 4.0 license http://creativecommons.org/licenses/by-nc-nd/4.0/ 


\begin{tabular}{|c|c|c|c|c|c|c|c|c|c|}
\hline OS-93711 & $0-18 \mathrm{cmBS}$ & & 5 & Picea & -25.84 & 1040 & 30 & $163^{\circ} 41.48778^{\prime} \mathrm{W}$ & $67^{\circ} 6.618^{\prime} \mathrm{N}$ \\
\hline OS-93935 & $70 \mathrm{cmBS}$ & & 5 & Picea & -25.40 & 1010 & 25 & $163^{\circ} 36.92796^{\prime} \mathrm{W}$ & $67^{\circ} 5.84976^{\prime} \mathrm{N}$ \\
\hline & $51 \mathrm{cmBD}$ & Level 5 & & Picea & & & & & \\
\hline OS-94063 & $51 \mathrm{cmBD}$ & Level 5 & 5 & & -23.41 & 1940 & 25 & $163^{\circ} 42.5904^{\prime} \mathrm{W}$ & $67^{\circ} 7.36014^{\prime} \mathrm{N}$ \\
\hline OS-93955 & $1-60 \mathrm{cmBS}$ & & 5 & Picea & -24.50 & 1620 & 35 & $163^{\circ} 44.25102^{\prime} \mathrm{W}$ & $67^{\circ} 8.22414^{\prime} \mathrm{N}$ \\
\hline OS-93957 & $8 \mathrm{cmBS}$ & & 5 & Betula & -26.03 & 1330 & 30 & $163^{\circ} 44.26194^{\prime} \mathrm{W}$ & $67^{\circ} 8.2134^{\prime} \mathrm{N}$ \\
\hline OS-93953 & $10 \mathrm{cmBS}$ & & 5 & Salicaceae & -26.06 & 505 & 25 & $163^{\circ} 44.35506^{\prime} \mathrm{W}$ & $67^{\circ} 8.2818^{\prime} \mathrm{N}$ \\
\hline OS-96757 & $8-10 \mathrm{cmbs}$ & & 5 & Betula & -26.52 & 385 & 20 & $163^{\circ} 44.27724^{\prime} \mathrm{W}$ & $67^{\circ} 8.25288^{\prime} \mathrm{N}$ \\
\hline & $8 \mathrm{cmBS}$ & & & Salicaceae & & & & & \\
\hline OS-93975 & (approx) & & 5 & & -25.18 & 325 & 30 & $163^{\circ} 44.27724^{\prime} \mathrm{W}$ & $67^{\circ} 8.25288^{\prime} \mathrm{N}$ \\
\hline OS-93751 & $3-6 \mathrm{cmBS}$ & & 6 & Picea & -26.00 & 920 & 25 & $163^{\circ} 41.10426^{\prime} \mathrm{W}$ & $67^{\circ} 6.34956^{\prime} \mathrm{N}$ \\
\hline OS-93759 & $5 \mathrm{cmBS}$ & & 6 & Betula & -23.67 & 370 & 25 & $163^{\circ} 41.17224^{\prime} \mathrm{W}$ & $67^{\circ} 6.35556^{\prime} \mathrm{N}$ \\
\hline OS-93750 & $5 \mathrm{cmBS}$ & & 6 & Picea & -25.42 & 390 & 25 & $163^{\circ} 41.37066^{\prime} \mathrm{W}$ & $67^{\circ} 6.40074^{\prime} \mathrm{N}$ \\
\hline OS-93753 & $6 \mathrm{cmBS}$ & & 6 & Picea & -24.34 & 275 & 25 & $163^{\circ} 41.48118^{\prime} \mathrm{W}$ & $67^{\circ} 6.42552^{\prime} \mathrm{N}$ \\
\hline OS-93764 & $14 \mathrm{cmBD}$ & & 6 & Betula & -27.73 & 160 & 25 & $163^{\circ} 41.48784^{\prime} \mathrm{W}$ & $67^{\circ} 6.44214^{\prime} \mathrm{N}$ \\
\hline OS-93752 & $30-35 \mathrm{cmBS}$ & & 6 & Salicaceae & -25.93 & 220 & 25 & $163^{\circ} 41.9286^{\prime} \mathrm{W}$ & $67^{\circ} 6.5592^{\prime} \mathrm{N}$ \\
\hline $\begin{array}{c}\text { Beta- } \\
326117 \\
\end{array}$ & $30-40$ cmBD & Level 4 & 6 & $\begin{array}{c}\text { Phoca, left 4th } \\
\text { metacarpal }\end{array}$ & -13.1 & 1410 & 30 & $163^{\circ} 41.2569^{\prime} \mathrm{W}$ & $67^{\circ} 6.39492^{\prime} \mathrm{N}$ \\
\hline $\begin{array}{l}\text { Beta- } \\
326120\end{array}$ & $30-40$ cmBD & Level 4 & 6 & $\begin{array}{l}\text { R. tarandus, C-2 } \\
\text { vertebra }\end{array}$ & -18.1 & 640 & 30 & $163^{\circ} 41.2569^{\prime} \mathrm{W}$ & $67^{\circ} 6.39492^{\prime} \mathrm{N}$ \\
\hline OS-94064 & $43 \mathrm{~cm} \mathrm{BD}$ & Level 5 & 6 & Salicaceae & -26.41 & 490 & 30 & $163^{\circ} 41.2569^{\prime} \mathrm{W}$ & $67^{\circ} 6.39492^{\prime} \mathrm{N}$ \\
\hline OS-93932 & $20 \mathrm{cmBD}$ & Level 2 & 6 & Salix & -24.45 & 645 & 30 & $163^{\circ} 41.3232^{\prime} \mathrm{W}$ & $67^{\circ} 6.41478^{\prime} \mathrm{N}$ \\
\hline OS-93937 & $53 \mathrm{cmBD}$ & Level 5 & 6 & Salicaceae & -24.51 & 9430 & 40 & $163^{\circ} 40.54578^{\prime} \mathrm{W}$ & $67^{\circ} 6.35148^{\prime} \mathrm{N}$ \\
\hline OS-93936 & $25 \mathrm{cmBD}$ & Level 2 & 6 & Salicaceae & -25.31 & 570 & 30 & $163^{\circ} 40.35894^{\prime} \mathrm{W}$ & $67^{\circ} 6.22806^{\prime} \mathrm{N}$ \\
\hline $\begin{array}{c}\text { Beta- } \\
326118 \\
\end{array}$ & $47 \mathrm{cmBD}$ & Level 4 & 6 & Phoca, rib & -13.0 & 1280 & 30 & $163^{\circ} 41.34852^{\prime} \mathrm{W}$ & $67^{\circ} 6.41922^{\prime} \mathrm{N}$ \\
\hline OS-96756 & $47 \mathrm{cmBD}$ & Level 4 & 6 & Salix & -26.1 & 765 & 35 & $163^{\circ} 41.34852^{\prime} \mathrm{W}$ & $67^{\circ} 6.41922^{\prime} \mathrm{N}$ \\
\hline OS-93940 & $28 \mathrm{cmBD}$ & Level 2 & 6 & Salicaceae & -25.24 & 715 & 25 & $163^{\circ} 41.34852^{\prime} \mathrm{W}$ & $67^{\circ} 6.41922^{\prime} \mathrm{N}$ \\
\hline & & & & Picea & & & & & \\
\hline OS-94049 & $30 \mathrm{BS}$ & & 6 & & -26.33 & 240 & 25 & $163^{\circ} 41.92962^{\prime} \mathrm{W}$ & $67^{\circ} 6.55926^{\prime} \mathrm{N}$ \\
\hline OS-93954 & $50-60 \mathrm{cmBS}$ & & 6 & Salix & -25.38 & 745 & 35 & $163^{\circ} 39.8655^{\prime} \mathrm{W}$ & $67^{\circ} 6.17904^{\prime} \mathrm{N}$ \\
\hline
\end{tabular}




\begin{tabular}{|c|c|c|c|c|c|c|c|c|c|}
\hline & approximately & & & Salicaceae & & & & & \\
\hline OS-93956 & $15 \mathrm{cmBS}$ & & 6 & & -25.04 & 875 & 25 & $163^{\circ} 39.59256^{\prime} \mathrm{W}$ & $67^{\circ} 6.14454^{\prime} \mathrm{N}$ \\
\hline $\begin{array}{c}\text { Beta- } \\
326106\end{array}$ & $20 \mathrm{CM}$ BS & & 6 & $\begin{array}{c}\text { Phoca, right } \\
\text { humerus }\end{array}$ & -12.8 & 1020 & 30 & $163^{\circ} 44.53536^{\prime} \mathrm{W}$ & $67^{\circ} 7.69482^{\prime} \mathrm{N}$ \\
\hline $\begin{array}{c}\text { Beta- } \\
326107\end{array}$ & $30 \mathrm{CM}$ BS & & 6 & $\begin{array}{c}\text { Phoca, right } \\
\text { calcaneus }\end{array}$ & -13.4 & 1110 & 30 & $163^{\circ} 44.5164^{\prime} \mathrm{W}$ & $67^{\circ} 7.60338^{\prime} \mathrm{N}$ \\
\hline $\begin{array}{c}\text { Beta- } \\
326113\end{array}$ & & Level 4 & 6 & cf. E. barbatus, rib & -13.0 & 1550 & 30 & $163^{\circ} 42.0708^{\prime} \mathrm{W}$ & $67^{\circ} 6.60324^{\prime} \mathrm{N}$ \\
\hline $\begin{array}{c}\text { Beta- } \\
326109\end{array}$ & $80 \mathrm{CM} \mathrm{BS}$ & & 6 & Phoca, left fibula & -13.5 & 1170 & 30 & $163^{\circ} 44.35986^{\prime} \mathrm{W}$ & $67^{\circ} 8.34642^{\prime} \mathrm{N}$ \\
\hline OS-93712 & $\begin{array}{l}45 \mathrm{cmBS} \\
\text { (approx) }\end{array}$ & & 6 & Picea & -26.10 & 975 & 25 & $163^{\circ} 41.28282^{\prime} \mathrm{W}$ & $67^{\circ} 6.46968^{\prime} \mathrm{N}$ \\
\hline OS-93689 & $62 \mathrm{cmBS}$ & & 6 & Picea & -25.13 & 965 & 25 & $163^{\circ} 41.2797^{\prime} \mathrm{W}$ & $67^{\circ} 6.46926^{\prime} \mathrm{N}$ \\
\hline OS-93713 & $52 \mathrm{cmBS}$ & & 6 & Picea & -23.62 & 810 & 25 & $163^{\circ} 41.12106^{\prime} \mathrm{W}$ & $67^{\circ} 6.4338^{\prime} \mathrm{N}$ \\
\hline OS-93714 & $12 \mathrm{cmBS}$ & & 6 & Picea & -25.74 & 830 & 30 & $163^{\circ} 40.98432^{\prime} \mathrm{W}$ & $67^{\circ} 6.40764^{\prime} \mathrm{N}$ \\
\hline OS-93716 & $16-20 \mathrm{cmBS}$ & & 6 & Picea & -25.18 & 910 & 30 & $163^{\circ} 40.97196^{\prime} \mathrm{W}$ & $67^{\circ} 6.41034^{\prime} \mathrm{N}$ \\
\hline OS-93715 & $22 \mathrm{cmBS}$ & & 6 & Picea & -27.07 & 1010 & 25 & $163^{\circ} 40.8909^{\prime} \mathrm{W}$ & $67^{\circ} 6.38706^{\prime} \mathrm{N}$ \\
\hline OS-94112 & $60 \mathrm{cmBS}$ & & 6 & Picea & -24.27 & 1140 & 25 & $163^{\circ} 40.65102^{\prime} \mathrm{W}$ & $67^{\circ} 6.3429^{\prime} \mathrm{N}$ \\
\hline OS-93718 & $65 \mathrm{~cm} \mathrm{BS}$ & & 6 & Conifer & -25.42 & 955 & 25 & $163^{\circ} 40.30464^{\prime} W$ & $67^{\circ} 6.27924^{\prime} \mathrm{N}$ \\
\hline OS-93757 & $40 \mathrm{cmBS}$ & & 6 & Picea & -24.05 & 1020 & 25 & $163^{\circ} 40.25124^{\prime} W$ & $67^{\circ} 6.27552^{\prime} \mathrm{N}$ \\
\hline OS-93719 & $5 \mathrm{cmBS}$ & & 6 & Picea & -23.30 & 630 & 25 & $163^{\circ} 40.36236^{\prime} \mathrm{W}$ & $67^{\circ} 6.24468^{\prime} \mathrm{N}$ \\
\hline OS-93897 & $5 \mathrm{cmBS}$ & & 6 & Salicaceae & -27.27 & 585 & 30 & $163^{\circ} 40.36236^{\prime} \mathrm{W}$ & $67^{\circ} 6.24468^{\prime} \mathrm{N}$ \\
\hline OS-93720 & Back fill & & 6 & Salix & -26.00 & 490 & 25 & $163^{\circ} 40.36236^{\prime} \mathrm{W}$ & $67^{\circ} 6.24468^{\prime} \mathrm{N}$ \\
\hline OS-93755 & $20 \mathrm{cmBS}$ & & 6 & Picea & -24.75 & 715 & 25 & $163^{\circ} 40.99404^{\prime} \mathrm{W}$ & $67^{\circ} 6.35106^{\prime} \mathrm{N}$ \\
\hline OS-93754 & $10 \mathrm{cmBS}$ & & 6 & Salicaceae & -26.90 & 665 & 25 & $163^{\circ} 41.23818^{\prime} \mathrm{W}$ & $67^{\circ} 6.39552^{\prime} \mathrm{N}$ \\
\hline OS-93758 & $36 \mathrm{cmBS}$ & & 6 & Salix & -27.72 & 745 & 25 & $163^{\circ} 41.25096^{\prime} \mathrm{W}$ & $67^{\circ} 6.39414^{\prime} \mathrm{N}$ \\
\hline OS-93879 & $33 \mathrm{cmBD}$ & Level 4 & 6 & Salicaceae & -25.07 & 585 & 25 & $163^{\circ} 41.21136^{\prime} \mathrm{W}$ & $67^{\circ} 6.40266^{\prime} \mathrm{N}$ \\
\hline $\begin{array}{c}\text { Beta- } \\
326116\end{array}$ & & Level 5 & 6 & $\begin{array}{c}\text { Phoca, right } \\
\text { navicular }\end{array}$ & -12.8 & 1450 & 30 & $163^{\circ} 41.23578^{\prime} \mathrm{W}$ & $67^{\circ} 6.41112^{\prime} \mathrm{N}$ \\
\hline OS-93880 & $88 \mathrm{cmBD}$ & Level 8 & 6 & Picea & -25.27 & 740 & 25 & $163^{\circ} 41.23578^{\prime} \mathrm{W}$ & $67^{\circ} 6.41112^{\prime} \mathrm{N}$ \\
\hline $\begin{array}{c}\text { Beta- } \\
326115\end{array}$ & & Level 5 & 6 & R. tarandus, antler & -20.1 & 510 & 30 & $163^{\circ} 41.23578^{\prime} \mathrm{W}$ & $67^{\circ} 6.41112^{\prime} \mathrm{N}$ \\
\hline OS-93763 & $16.5 \mathrm{cmBD}$ & Level 1 & 6 & Picea & -26.90 & 290 & 35 & $163^{\circ} 41.23578^{\prime} \mathrm{W}$ & $67^{\circ} 6.41112^{\prime} \mathrm{N}$ \\
\hline
\end{tabular}


Anderson et al. 2018 Supplemental Table 2: New Archaeological Radiocarbon Dates

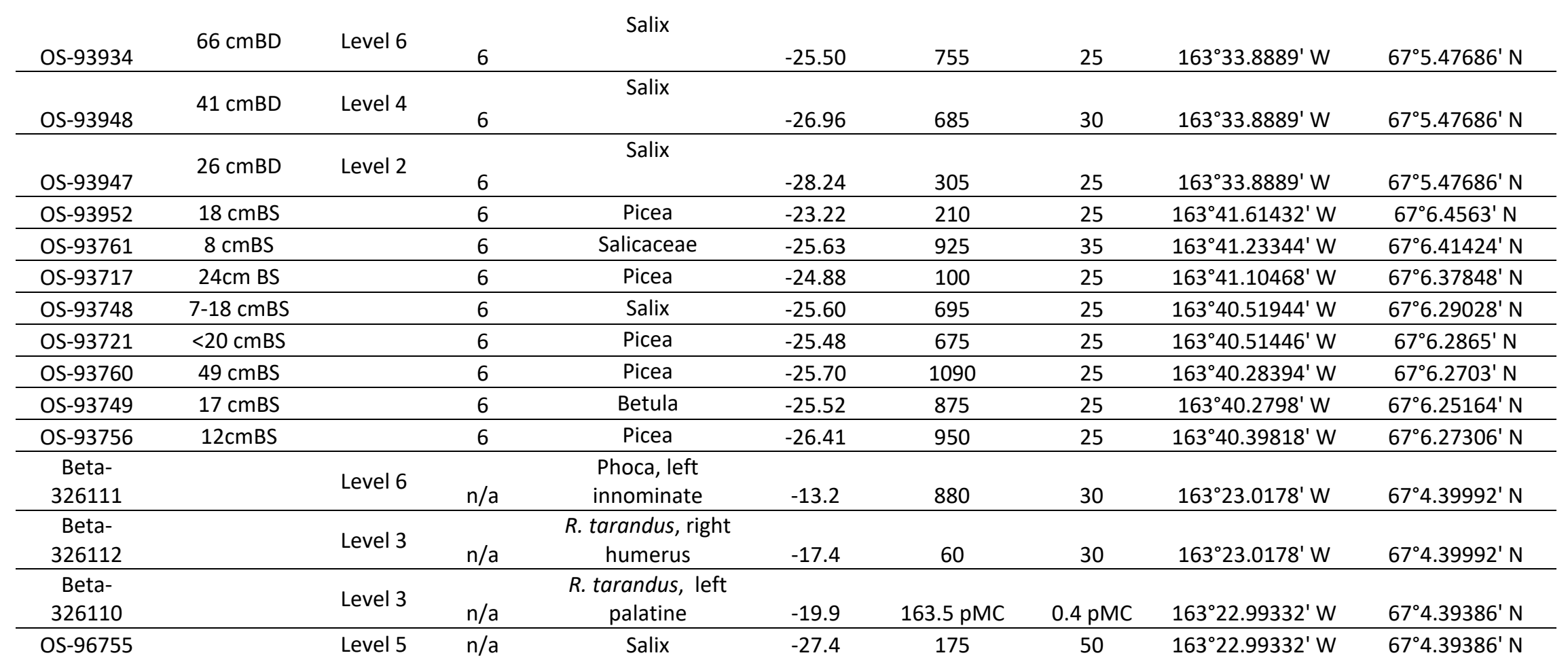


Supplemental Table 2. GPS Locations for Geomorphological Samples

\begin{tabular}{|c|c|c|c|}
\hline Field Number & $\begin{array}{c}\text { Beach } \\
\text { Segments }\end{array}$ & Longitude & Latitude \\
\hline 08-CK-10-9 & 1 & $163^{\circ} 42.312^{\prime} \mathrm{W}$ & $67^{\circ} 8.288^{\prime} \mathrm{N}$ \\
\hline 08-CK-10-55 & 1 & $163^{\circ} 42.312^{\prime} \mathrm{W}$ & $67^{\circ} 8.288^{\prime} \mathrm{N}$ \\
\hline 08-CK-10-24 & 1 & $163^{\circ} 42.312^{\prime} \mathrm{W}$ & $67^{\circ} 8.288^{\prime} \mathrm{N}$ \\
\hline 08-CK-10-29 & I & $163^{\circ} 42.312^{\prime} \mathrm{W}$ & $67^{\circ} 8.288^{\prime} \mathrm{N}$ \\
\hline 08-CK-4-18 & I & $163^{\circ} 31.378^{\prime} \mathrm{W}$ & $67^{\circ} 7.017^{\prime} \mathrm{N}$ \\
\hline 08-CK-11 & I & $163^{\circ} 42.631^{\prime} \mathrm{W}$ & $67^{\circ} 8.251^{\prime} \mathrm{N}$ \\
\hline 09-CK-14-20 & I & $163^{\circ} 41.568^{\prime} \mathrm{W}$ & $67^{\circ} 7.898^{\prime} \mathrm{N}$ \\
\hline 08-CK-13 & 1 & $163^{\circ} 40.739^{\prime} \mathrm{W}$ & $67^{\circ} 7.650^{\prime} \mathrm{N}$ \\
\hline 09-CK-14-30 & 1 & $163^{\circ} 41.568^{\prime} \mathrm{W}$ & $67^{\circ} 7.898^{\prime} \mathrm{N}$ \\
\hline $08-C K-22$ & 1 & $163^{\circ} 41.043^{\prime} \mathrm{W}$ & $67^{\circ} 7.141^{\prime} \mathrm{N}$ \\
\hline $08-C K-4-22$ & I & $163^{\circ} 31.378^{\prime} \mathrm{W}$ & $67^{\circ} 7.017^{\prime} \mathrm{N}$ \\
\hline 09-CK-3 & I & $163^{\circ} 38.917^{\prime} \mathrm{W}$ & $67^{\circ} 7.094^{\prime} \mathrm{N}$ \\
\hline $08-C K-4-4$ & 1 & $163^{\circ} 31.378^{\prime} \mathrm{W}$ & $67^{\circ} 7.017^{\prime} \mathrm{N}$ \\
\hline 08-CK-8-49 & Ila & $163^{\circ} 30.640^{\prime} \mathrm{W}$ & $67^{\circ} 6.138^{\prime} \mathrm{N}$ \\
\hline 08-CK-8-61 & Ila & $163^{\circ} 30.640^{\prime} \mathrm{W}$ & $67^{\circ} 6.138^{\prime} \mathrm{N}$ \\
\hline $08-C K-24$ & III & $163^{\circ} 43.592^{\prime} \mathrm{W}$ & $67^{\circ} 8.070^{\prime} \mathrm{N}$ \\
\hline CAKR09-0214 & III & $163^{\circ} 40.258^{\prime} \mathrm{W}$ & $67^{\circ} 6.874^{\prime} \mathrm{N}$ \\
\hline 09-CK-7 & III & $163^{\circ} 40.327^{\prime} \mathrm{W}$ & $67^{\circ} 6.907^{\prime} \mathrm{N}$ \\
\hline 08-CK-23 & IV & $163^{\circ} 44.203^{\prime} \mathrm{W}$ & $67^{\circ} 8.237^{\prime} \mathrm{N}$ \\
\hline CAKR09-0354 & IV & $163^{\circ} 39.865^{\prime} \mathrm{W}$ & $67^{\circ} 6.693^{\prime} \mathrm{N}$ \\
\hline 08-CK-26 & IV & $163^{\circ} 36.883^{\prime} \mathrm{W}$ & $67^{\circ} 6.213^{\prime} \mathrm{N}$ \\
\hline 09-CK-16 & $\mathrm{V}$ & $163^{\circ} 39.911^{\prime} \mathrm{W}$ & $67^{\circ} 6.542^{\prime} \mathrm{N}$ \\
\hline 09-CK-1 & $\mathrm{V}$ & $163^{\circ} 44.267^{\prime} \mathrm{W}$ & $67^{\circ} 8.099^{\prime} \mathrm{N}$ \\
\hline 09-СК-2 & $\mathrm{V}$ & $163^{\circ} 42.077^{\prime} \mathrm{W}$ & $67^{\circ} 6.673^{\prime} \mathrm{N}$ \\
\hline CAKR08-0259 & $\mathrm{V}$ & $163^{\circ} 36.328^{\prime} \mathrm{W}$ & $67^{\circ} 5.783^{\prime} \mathrm{N}$ \\
\hline CAKR09-0267 & $\mathrm{V}$ & $163^{\circ} 39.424^{\prime} \mathrm{W}$ & $67^{\circ} 6.487^{\prime} \mathrm{N}$ \\
\hline CAKR09-0264 & $\mathrm{V}$ & $163^{\circ} 39.232^{\prime} \mathrm{W}$ & $67^{\circ} 6.511^{\prime} \mathrm{N}$ \\
\hline 09-CK-17 & $\mathrm{V}$ & $163^{\circ} 41.204^{\prime} \mathrm{W}$ & $67^{\circ} 6.931^{\prime} \mathrm{N}$ \\
\hline CAKR09-0285 & $\mathrm{V}$ & $163^{\circ} 39.604^{\prime} \mathrm{W}$ & $67^{\circ} 6.535^{\prime} \mathrm{N}$ \\
\hline CAKR10-0024 & VIb & $163^{\circ} 41.798^{\prime} \mathrm{W}$ & $67^{\circ} 6.578^{\prime} \mathrm{N}$ \\
\hline CAKR10-0352 & $\mathrm{VIb}$ & $163^{\circ} 40.377^{\prime} \mathrm{W}$ & $67^{\circ} 6.325^{\prime} \mathrm{N}$ \\
\hline $08-C K-15-37$ & $\mathrm{n} / \mathrm{a} *$ & $163^{\circ} 26.874^{\prime} \mathrm{W}$ & $67^{\circ} 5.815^{\prime} \mathrm{N}$ \\
\hline 08-CK-14-127 & $\mathrm{n} / \mathrm{a} *$ & $163^{\circ} 26.801^{\prime} \mathrm{W}$ & $67^{\circ} 5.855^{\prime} \mathrm{N}$ \\
\hline
\end{tabular}

*Dates obtained SE of beach ridge complex in Tukrok Wetlands, not directly associated with a beach ridge set 